\title{
Reducing Morbidity and Mortality Rates from COVID-19, Influenza and Pneumococcal Illness in Nursing Homes and Long-Term Care Facilities by Vaccination and Comprehensive Infection Control Interventions
}

\author{
Roger E. Thomas (D)
}

check for

updates

Citation: Thomas, R.E. Reducing Morbidity and Mortality Rates from COVID-19, Influenza and

Pneumococcal Illness in Nursing

Homes and Long-Term Care Facilities by Vaccination and Comprehensive Infection Control Interventions. Geriatrics 2021, 6, 48. https:// doi.org/10.3390/geriatrics6020048

Academic Editor: Phyo Kyaw Myint

Received: 14 February 2021

Accepted: 6 May 2021

Published: 8 May 2021

Publisher's Note: MDPI stays neutral with regard to jurisdictional claims in published maps and institutional affiliations.

Copyright: (C) 2021 by the author. Licensee MDPI, Basel, Switzerland. This article is an open access article distributed under the terms and conditions of the Creative Commons Attribution (CC BY) license (https:// creativecommons.org/licenses/by/ $4.0 /)$.
Department of Family Medicine, Faculty of Medicine, University of Calgary, Calgary, AB T2M 1M1, Canada; rthomas@ucalgary.ca

Abstract: The COVID-19 pandemic identifies the problems of preventing respiratory illnesses in seniors, especially frail multimorbidity seniors in nursing homes and Long-Term Care Facilities (LCTFs). Medline and Embase were searched for nursing homes, long-term care facilities, respiratory tract infections, disease transmission, infection control, mortality, systematic reviews and metaanalyses. For seniors, there is strong evidence to vaccinate against influenza, SARS-CoV-2 and pneumococcal disease, and evidence is awaited for effectiveness against COVID-19 variants and when to revaccinate. There is strong evidence to promptly introduce comprehensive infection control interventions in LCFTs: no admissions from inpatient wards with COVID-19 patients; quarantine and monitor new admissions in single-patient rooms; screen residents, staff and visitors daily for temperature and symptoms; and staff work in only one home. Depending on the vaccination situation and the current risk situation, visiting restrictions and meals in the residents' own rooms may be necessary, and reduce crowding with individual patient rooms. Regional LTCF administrators should closely monitor and provide staff and PPE resources. The CDC COVID-19 tool measures 33 infection control indicators. Hand washing, social distancing, PPE (gowns, gloves, masks, eye protection), enhanced cleaning of rooms and high-touch surfaces need comprehensive implementation while awaiting more studies at low risk of bias. Individual ventilation with HEPA filters for all patient and common rooms and hallways is needed.

Keywords: nursing homes; long-term care homes; respiratory infections; COVID-19; influenza; pneumococcal illness; comprehensive infection control interventions; individual room fresh air entry and venting; automatically triggered interventions

\section{Introduction}

In healthy seniors, influenza viruses, SARS-CoV-2, respiratory syncytial virus (RSV) and human metapneumovirus (hMNV) are the most frequent causes of viral pneumonia, and adenoviruses, rhinoviruses and parainfluenza viruses are less common. Immunocompromised seniors are a highly at-risk group of patients in LTCFs and nursing homes and are at risk from the same viruses together with reactivating latent viruses, such as cytomegalovirus, herpes simplex virus and adenoviruses. A specific pathogen is not identified in a third of large surveillance studies of community-acquired pneumonia, either because peak shedding has occurred or the viral titre is low. When all nucleic acids in samples are sequenced, a clearer picture of individual and population bioviromes will be obtained. Pneumococcal pneumonia is the most important bacterial cause of pneumonia.

In this article on individuals $\geq 65$ in nursing homes and LTCFs, the focus is on the five most frequent pathogens: influenza, respiratory syncytial virus, SARS-CoV-2, hMNV and pneumococcal pneumonia and invasive pneumococcal disease [1], their outcomes in seniors and frail multimorbidity seniors, and the interventions needed in nursing homes and LTCFs to minimise mortality. 
Influenza is a single-stranded, segmented, negative-sense, RNA virus in the Orthomyxoviridae family. Serotypes A and C infect multiple species and B almost exclusively humans. As influenza A viruses have 18 different hemagglutinin $(\mathrm{H})$ and 11 neuraminidase $(\mathrm{N})$ surface protein subtypes, reassortment can cause major pandemics: H1N1 (1918 pandemic), H2N2 (1957 pandemic), H3N2 (1968 pandemic), H1N1pdm2009 (2009 pandemic) and H1N1, H3N2 and type B viruses cause annual seasonal epidemics. As up to $10 \%$ of cases of influenza pneumonia are accompanied by staphylococcal and streptococcal bacterial pneumonia, it is especially serious for the elderly with an increased risk of mortality and death within three weeks due additionally to heart failure. Pandemics can occur due to transmission from animals: influenza viruses are frequent in the gastrointestinal tracts of birds, and if they settle on a farm with pigs (whose lungs possess receptors for both human and avian influenza), the pigs can reassort the avian influenza to be infective for humans. The transmission of H5N1, H7N7 and H7N9 influenza viruses can occur from chickens to humans, with major epidemics of H5N1 in 1997 in Hong Kong and H7N9 in 2013 in China [1].

RSV is a single-stranded, negative-sense, nonsegmented, RNA virus of the Paramyxoviridae family and is a frequent cause of infection in both children and the elderly. In the elderly, RSV is an important causes of hospitalisation, with the same pattern of heart failure and requirement of major clinical support as influenza [1].

Human metapneumovirus (hMPV) is also a member of the Paramyxoviridae family and causes about $50 \%$ fewer lower respiratory tract infections than RSV, probably because it does not contain the genes that RSV expresses in infected host cells to negate the effectiveness of the patient's immune system [1].

SARS-CoV-2 is a member of the Coronaviridae genus. The first major epidemic (November 2002 through July 2003) involved > 8000 cases with a 10\% mortality rate, the Middle East respiratory syndrome coronavirus (MERS-CoV-2) epidemic in 2012 had a 35\% mortality rate, and in the current pandemic more than $80 \%$ of deaths have occurred in the frail elderly. The virus is endemic in bats with the infection of civet cats in 2002-3, MERS in 2012 in bats with humans acquiring it from dromedaries, and in the current pandemic the initial exchange began with infection from bats to pangolins [1]. More than 36 animal species are known to chronically harbour coronaviruses.

The COVID-19 pandemic has provided important evidence of the problems of preventing respiratory illness in seniors, especially frail seniors with multimorbidity in nursing homes and LTCFs. In the US, the CDC reported that $80 \%$ of deaths from COVID-19 were in those $>65$ and there were sharply increasing rates above the age of 65 [2] (Table 1), and it has caused a pandemic comparable in worldwide spread to the 1918 influenza pandemic. The purpose of this article is to examine optimum strategies that nursing homes and LTCFs should implement to minimise mortality from all respiratory viruses.

Table 1. COVID-19 hospitalisation and death rates, USA, for age groups 18-29 to 85+.

\begin{tabular}{ccc}
\hline Age Group & Hospitalisation Rate & Death Rate \\
\hline $18-29$ years & Comparison Group & Comparison Group \\
\hline $30-39$ years & $2 x$ higher & $4 x$ higher \\
\hline $40-49$ years & $3 x$ higher & $10 x$ higher \\
\hline $50-64$ years & $4 x$ higher & $30 x$ higher \\
\hline $65-74$ years & $5 x$ higher & $90 x$ higher \\
\hline $75-84$ years & $8 x$ higher & $220 x$ higher \\
\hline $85+$ years & $13 x$ higher & $630 x$ higher \\
\hline
\end{tabular}

A multi-country study compared mortality rates for different age groups from COVID-19 over a six-week period to May 82020 for the 21 countries with the highest recorded number of cases of COVID-19 (Austria, Belgium, Brazil, Canada, China, France, Germany, India, 
Iran, Israel, Italy, Netherlands, Portugal, Russia, South Korea, Spain, Sweden, Switzerland, Turkey, the United Kingdom, and the United States). Compared to COVID-19 deaths in those $\leq 54$ years, for those 55-64 years the incident rate ratio (IRR) was 8.1 (95\% confidence interval (CI) 7.7 to 8.5 ), for those $\geq 65$ years the IRR was 62.1 (59.7 to 64.7), and for males the IRR was 1.77 (1.74 to 1.79) [3].

\section{Purposes}

To identify in nursing homes and LTCFs: (1) The numbers of patients infected with respiratory tract infections, risk factors and mortality. (2) The effectiveness of vaccination against respiratory illnesses for residents in nursing homes and LTCFs and the healthcare workers (HCW) who care for them, and methods of increasing vaccination rates for SARS-CoV-2, influenza, and pneumococci which cause pneumonia and invasive pneumococcal disease. (3) The effectiveness of comprehensive interventions to reduce rates of respiratory illnesses using vaccination, hand washing, PPE (masks, eye protection, gloves, waterproof gowns), comprehensive infection control strategies such as the CDC indictors of care, a reduction in crowding in homes, the provision of isolation wings and rooms in nursing homes and LTCFs, and air flow redesign in existing and new homes to reduce the prevalence of mortality from respiratory tract infections in nursing homes and LTCFs. (4) Assess which preventive interventions function automatically and which for effectiveness are most and least dependent for the completeness of their performance on the continued diligence of the participants.

\section{Materials and Methods}

Literature Search

Medline and Embase were searched on 4 January 2021 and again on 9 March 2021 (Table 2). All search terms were used with the .mp suffix rather than the MeSH headings as this provides a wider search. The titles and abstracts of all studies in searches 10, 12, 16, 20 and 22 were read and then relevant studies selected and read in full text.

Table 2. Literature searches 9 March 2021 in Medline and Embase.

\begin{tabular}{cccc}
\hline & Search Term & Medline & Embase \\
\hline 1 & coronavirus.mp. & 81468 & 125824 \\
\hline 2 & Sars-CoV-2.mp. or exp SARS-CoV-2/ & 68254 & 35064 \\
\hline 3 & Covid-19.mp. & 107186 & 96515 \\
\hline 4 & 1 or 2 or 3 & 125192 & 131716 \\
\hline 5 & nursing home.mp. & 22862 & 63414 \\
\hline 6 & homes for the aged.mp. & 14435 & 746 \\
\hline 7 & long term care.mp. & 39334 & 142648 \\
\hline 8 & long term care facilities.mp. & 4389 & 5579 \\
\hline 9 & 5 or 6 or 7 or 8 & 67177 & 195407 \\
\hline 10 & 4 and 9 & 722 & 1288 \\
\hline 11 & mortality.mp. & 1206828 & 1564538 \\
\hline 12 & 10 and 11 & 186 & 383 \\
\hline 13 & Disease transmission & 40060 & 107336 \\
\hline 14 & disease transmission, infectious.mp. & 10443 & 58 \\
\hline
\end{tabular}


Table 2. Cont.

\begin{tabular}{cccc}
\hline & Search Term & Medline & Embase \\
\hline 15 & respiratory tract infections.mp. & 47170 & 22062 \\
\hline 16 & negative pressure isolation.mp. & 73 & 94 \\
\hline 17 & systematic review.mp. & 206869 & 364785 \\
\hline 18 & meta-analysis.mp. & 208052 & 312070 \\
\hline 19 & 17 or 18 & 318737 & 513093 \\
\hline 20 & 10 and 19 & 9 & 27 \\
\hline 21 & 13 or 14 or 15 & 87017 & 129231 \\
\hline 22 & 10 and 21 & 37 & 42 \\
\hline
\end{tabular}

\section{Results}

\subsection{Frail Health Status of Nursing Home and LTCF Residents}

Some seniors elect to move to lodges and senior residencies, and others need more intermittent or continued care in nursing homes. Nursing homes and LTCFs vary from low care-requirement homes where patients are provided meals with intermittent care for health problems but are expected to look after all other aspects of their care, to high care-requirement homes with most patients having high rates of frailty, comorbidity and dependence. In high care-requirement homes, nursing care intensity and difficulty are increased and involve major workloads, including coping with crises (e.g., falls, consequences of dementia, depression and aggression, new acute illnesses such as pneumonia and referring ill patients to hospital), assessing, examining and measuring physical signs, completing measuring scales for monitoring purposes and regulatory agencies, taking samples and sending them to the laboratory, data entry on computers, administering medications and treatments, discussing their care with colleagues and family members, providing food (some patients need puree food fed one spoon at a time), toileting, diaper changing, turning in bed to avoid bedsores, laundry, escorting to dining rooms, and socialising with and encouraging patients.

Respiratory pandemics such as SARS-CoV-2 or influenza markedly increase demands for skilled care and transfers to hospital. Some homes care for many very ill patients with consequent short stays to the time of their death, and a study in Norway is an example of such homes with a median survival of 2.2 years and with acuity which would require all respiratory illness reduction strategies [4]. Nursing homes in Iceland, Ireland and the US had similar median survival times between 2.3 and 2.8 years [5-9], a register-based study in Norway 1994-2004 2.1 years [10], and a study in France an annual mortality rate of $17.4 \%$ [11]. The acuity of care is illustrated by a systematic review of transfers to hospital for emergency care: 59\% were triaged as urgent or emergent compared to $45 \%$ of all emergency department presentations and 1-5\% died in the emergency department, 5-34\% after admission to hospital and 12-29\% within a month of discharge [12] (Table 3). Patients have high levels of chronic comorbidities [13,14]. 
Table 3. Numbers of patients in nursing homes and LCTFs, disabilities, mortality rates and respiratory infections.

\begin{tabular}{|c|c|}
\hline \multicolumn{2}{|c|}{ Numbers of Patients in LCTFs and Nursing Homes, Disabili } \\
\hline Author, Date & Setting \\
\hline Vossius 2018 [4] & $\begin{array}{l}47 \text { small and large nursing homes in urban } \\
\text { and rural areas in } 4 \text { Norwegian counties } \\
\text { followed for } 3 \text { years. Average age } 84.5 \text { years, } \\
83.9 \% \text { dementia at baseline. } \\
\text { Assessment: Trained healthcare workers } \\
\text { (74\% registered nurses, } 2 \text { days of training) } \\
\text { collected data using structured interviews } \\
\text { with patient and caregiver, supervised by } \\
10 \text { research nurses ( } 5 \text { days training). } \\
\text { Dementia assessments by } 2 \text { psychiatrists } \\
\text { (adjudicated by a 3rd), ICD-10, Clinical } \\
\text { Dementia Rating Scale (CDR), } \\
\text { neuropsychiatric symptoms by the } \\
\text { Neuropsychiatric Inventory nursing home } \\
\text { version (NPI-NH), self-care by the Physical } \\
\text { Self-Maintenance Scale (PSMS), general } \\
\text { health by General Medical Health Rating } \\
\text { (GMHR), comorbidities by Charlson's } \\
\text { comorbidity index. }\end{array}$ \\
\hline
\end{tabular}

Systematic review of 83 studies of emergency transfers to hospital of residents of LTCFs $\geq 65$ years.
Dwyer 2014 [12]

Canadian Institute of Health Information 2020 [13]

Harris-Kojetin 2018 [14]

\section{Numbers of nursing home patients in Canada: 2019-2020 there were 189,662 residents in 1318 nursing homes; average age 83 years, $54 \% \geq 85,65 \%$ female. Risk factors: Cognitive Performance Scale (CPS) $\geq 4$, Index of Social Engagement (ISE) $\leq 2$, the Aggressive Behaviour Scale $(\mathrm{ABS}) \geq 1$, and the Pain Scale $\geq 2$.}

Numbers of nursing home patients: $1,347,600$ residents in 15,600 nursing homes. Multiple types of long-term care: In US in 2016 there were 65,600 remunerated regulated long-term care services, providing care for $>8.3$ million people in five sectors: estimated 286,300 individuals in 4600 adult day services centers, 811,500 residents in residential care communities,

$1,426,000$ patients receiving services from 4300 hospices and residents in 28,900 assisted living residential care communities. In 2015, $\sim 4,455,700$ patients discharged annually from home health agencies.
Triage assessment in emergency departments: $59 \%$ triaged urgent or emergent compared to $45 \%$ of all emergency department presentations.

Reasons for admission: multiple illnesses: respiratory tract infections $(12-37 \%$ of all presentations), other infections (6-24\%), falls $(12-23 \%)$, fractures and orthopedic injuries (7-24\%), cardiovascular illness (11-28\%), altered mental state (7-12\%).

Mortality: $1-5 \%$ died in the emergency department, $5-34 \%$ after admission to hospital and $12-29 \%$ within a month of discharge.

Morbidities: $61.6 \%$ dementia, 59\% hypertension, $24.5 \%$ signs of depression, $24.8 \%$ diabetes, $9 \%$ cancer, $77 \%$ some urinary incontinence, $59 \%$ some bowel incontinence, $42.9 \%$ little or no social engagement, $12 \%$ total dependence for Activities of Daily Living (ADLs), 9\% daily pain.

Morbidities in nursing home patients: $72 \%$ hypertension, $48 \%$ dementia, $46 \%$ depression, $38 \%$ heart disease, $32 \%$ diabetes, $26 \%$ arthritis, and $12 \%$ osteoporosis.

Hours of staff care time: If staff used every hour for patient care, in nursing homes daily per patient RNs could provide 0.54 hours of care, licensed practical or vocational nurses 0.85 , aides 2.4 , social workers 0.08 ; in residential care, $0.2,0.17,2.27$ and $0.03 \mathrm{~h}$, respectively. 


\subsection{Infections and Respiratory Infections in Nursing Homes and LTCFs}

Systematic reviews of infections in LCTFs identified wide variations in reported respiratory illness rates, higher attack rates for viral than bacterial outbreaks, and inadequate control measures in many studies [15-17] (Table 4). There is considerable scope for increasing influenza vaccination rates in seniors, and for 26 million Medicare fee-for-service patents the highest rates were $57.9 \%$ in both the $80-84$ and $85-89$ age groups, with marked decreases in the age groups 90+ [18]. For those $\geq 65$ in Canada, the estimated rate in 2020 was $70.3 \%(95 \%$ CI 66.7, 73.8) [19]. In a study in Alicante, Spain, patients hospitalised with influenza had more chronic disabilities and the mortality rate was $19 \%$ for those $\geq 65$ compared to $2.9 \%$ for those $<65$ [20]. Vaccine effectiveness is lower as seniors increase in age and infection protection measures become increasingly important.

Studies of COVID-19 in nursing homes and LTCFs demonstrate the large percentages of patients and staff who are asymptomatic, the rapidity of the spread of epidemics from a single case [21], the necessity for proactive comprehensive control strategies instituted before any cases occur, and the imperative to institute lockdown and comprehensive control strategies immediately the first case is identified (Table 4). The rapidity of the spread of COVID-19 was illustrated in an LCTF in Washington State which identified the first case on 28 February - by 18 March there were 167 confirmed COVID-19 cases (101 residents, 50 HCWs, 16 visitors) epidemiologically linked to the facility, and hospitalisation rates for COVID-19 positive residents were $54.5 \%$, visitors $50.0 \%$, staff $6.0 \%$ and there were 34 deaths in residents. On 10 March 2020, the state governor implemented mandatory screening of health care workers and visitor restrictions for all LCTFs and clinical monitoring, social distancing, and restriction of resident movement and group activities [22]. Similarly, in Ireland the first case occurred on 29 February 2020, and in a national survey 18 April to 5 May 2020, in the Dublin region the confirmed COVID-19 rate for residents was $40.8 \%$ (25\% asymptomatic), the case fatality rate was $25.8 \%$, and for staff the confirmed rate was $33.6 \%$ (27.6\% asymptomatic) [23].

Progression to severe disease can be rapid in older seniors with multiple comorbidities. In a retrospective cohort study of 832 consecutive COVID-19 admissions 4 March to 24 April 2020 in five hospitals in Maryland and Washington, DC, 787 patients were admitted with mild to moderate disease and 45 with severe disease (measured with the WHO scale) [24], and at discharge $523(63 \%)$ had experienced mild to moderate disease, $171(20 \%)$ severe disease and $131(16 \%)$ died. Progression to severe disease or death was rapid and occurred in $181(60 \%)$ by day 2 and $238(79 \%)$ by day 4 [25].

Mortality rates are markedly higher for older seniors. In a national study in Norway of all individuals who tested positive for SARS-CoV-2 by the end of June 2020, for those $\geq$ 90 the risks of hospitalisation $(R R=9.5 ; 7.1,12.7)$ and death $(R R=607.9 ; 145.5,2540.1)$ were much higher than for those $<50$ years and the risk of death for nursing home residents was higher $(\mathrm{RR}=4.2 ; 3.1,5.7)$ [26]. Mortality rates vary with the quality of care and were much higher in homes in France [27] with poorer clinical care, and in California outbreak sizes were 13 times larger in for-profit than in non-profit homes [28]. Mortality rates can vary widely between regions, and the wide variations in mortality rates between Italian regions have not yet been elucidated [29]. 
Table 4. Respiratory infections in nursing homes and LTCFs.

\begin{tabular}{|c|c|c|}
\hline \multicolumn{3}{|c|}{ Infections and Respiratory Infections in LTCFs and Nursing Homes } \\
\hline Author, Date & Setting & Disabilities and Mortality Rates \\
\hline Lee 2020 [15] & $\begin{array}{l}\text { Systematic review of } 37 \text { studies of } \\
\text { infections in LCTFs: Risk of bias assessed } \\
\text { with Risk of Bias Assessment tool for } \\
\text { Nonrandomized Study (RoBANS) [16]. Only } \\
6 \text { studies at low risk for all criteria, with } \\
\text { problems with recall bias and self-reported } \\
\text { measurement in } 7 \text { studies, problems with } \\
\text { confounders in } 4 \text { studies and missing data in } \\
5 \text { studies. No meta-analysis performed. }\end{array}$ & $\begin{array}{l}\mathbf{1 3 3 2} \text { infection outbreaks: most commonly } \\
\text { reported pathogens influenza and Group A } \\
\text { streptococcus. In } 29 \text { studies median attack } \\
\text { rate } 15.7 \% \text { ( } 8.3 \% \text { for bacterial and } 19.3 \% \text { for } \\
\text { viral outbreaks); } 25 \text { studies identified causes, } \\
\text { half documented person-to-person } \\
\text { transmission (involving poor hand hygiene } \\
\text { and decontamination), only } 9 \text { promptly } \\
\text { involved public health authorities, } 5 \text { studies } \\
\text { reported creation of outbreak control teams; } \\
60 \% \text { of studies reported cases among staff, } \\
\text { few studies implemented work restrictions. }\end{array}$ \\
\hline Childs 2019 [17] & $\begin{array}{l}\text { Systematic review of } 26 \text { articles reporting } \\
\text { respiratory infections in LCTFs: in } \\
\text { unvaccinated residents } \geq 60 \text { years in LCTFs } \\
1964-2019 \text { to assess burden of respiratory } \\
\text { infections in unvaccinated residents; average } \\
\text { ages } 70.8 \text { to } 90.1 \text { years. }\end{array}$ & $\begin{array}{l}\text { Respiratory infection incidence and } \\
\text { prevalence rates in LTCFs: varied widely } \\
\text { and attributed partly to seasonality. } \\
\text { Influenza incidence rates ranged from } 5.9 \% \\
\text { to } 85.2 \% \text {, RSV incidence } 1.1 \% \text { to } 13.5 \% \text {, } \\
\text { pneumonia incidence rates } 4.8 \% \text { to } 41.2 \% \text {. } \\
\text { Policy recommendations need to be based on } \\
\text { well-designed epidemiologic studies in large } \\
\text { populations with assessments for seasonality } \\
\text { and risk factors in specific homes and } \\
\text { populations. }\end{array}$ \\
\hline
\end{tabular}

Influenza Rates in the Community and in LCTFs

Retrospective cohort study of $\mathbf{2 6}$ million Influenza vaccination by age quintiles: US Medicare fee-for-service patients $\geq 65$ : 2015-2017

Shen 2019 [18]

Public Health Agency of Canada 2021 [19]

Ramos 2016 [20]
National survey of influenza vaccination rates, Canada: 2019-2020

Retrospective study of 219 influenza patients: admitted to General University Hospital of Alicante, Spain, 1 January to 31 April 2015, diagnosed with influenza by molecular biology tests.
65-69 (44.2\%), 70-74 (52.2\%), 75-79 (56.3\%) 80-84 (57.9\%), 85-89 (57.9\%), 90-94 (54.8\%), 95-99 (49.9\%), and 100+ (35.8\%) [20]. For US nursing homes the Minimum Data Set of the US Centers for Medicare and Medicaid Services found influenza vaccination coverage increased from $71.4 \%$ in the 2005-2006 influenza season to $75.7 \%$ in the 2014-2015 season, but there were large variations by state in influenza vaccination coverage (50.0\% to $89.7 \%$ ) in the $2014-2015$ influenza season.

Vaccination rate by age groups: for 18-64 $34.1 \%$ (95\% CI 31.8, 36.5); 18-64 with serious health conditions $43.6 \%$ (95\% CI 39.0, $48.1) ; \geq 6570.3 \%$ (95\% CI 66.7, 73.8).

Risk factors for patients $\geq \mathbf{8 0}$ compared to those < 65: had lower average glomerular filtration rates $(49.7 \mathrm{~mL} / \mathrm{min}$ vs. $62.2 \mathrm{~mL} / \mathrm{min} ; p=0.006$ ), higher rates of non-invasive mechanical ventilation $(22 \% \mathrm{vs}$. $9.3 \% ; p=0.02)$, higher rates of cardiac insufficiency ( $40.5 \%$ vs. $16.4 \%$; $p<0.001)$, chronic renal disease ( 32.9 vs. $20 \%$; $p=0.03$ ), and mortality $(19 \%$ vs. $2.9 \% ; p<0.001$; adjusted OR 9.2 (95\% Confidence Interval [CI] 1.65 to 51.1$)$ ). 
Table 4. Cont.

\begin{tabular}{lc}
\hline & Infections and Respiratory Infections in LTCFs and \\
\hline Author, Date & \multicolumn{1}{c}{ Setting } \\
\hline & Coronavirus in LCTFs \\
\hline & Retrospective COVID-19 cohort study in \\
& LCTF: March 2020 of patients in an academic \\
& long-term chronic care facility in Boston, \\
& USA. Patient data and clinical symptoms \\
& from electronic medical records and \\
& Minimum Data Set, COVID-19 status by PCR \\
& testing of nasopharyngeal swabs; staff \\
& residence from zip codes.
\end{tabular}

Progression of COVID-19 epidemic in

LTCF: King County, Washington State, USA. Confirmed COVID-19 case identified 28 February 282020.
Higher mortality rates among the frail patients: Of 389 long-stay residents 146 (37.5\%) tested positive for COVID-19 and of these 66 of the 146 (45.5\%) were asymptomatic.

Wide variation between nursing units in COVID-19 rates: Nursing units varied widely (0-90.5\%) in percentage COVID-19 positive. Of the COVID-19 positive residents $44(30.1 \%)$ died $(22.2 \%$ of the moderately frail and $50.0 \%$ of the frail; $p<0.001)$. In LCTF units $6 \%(95 \%$ CI $1.04,1.08)$ increase in positive COVID-19 tests for each 10\% increase in percentage of staff living in communities with high COVID-19 prevalence.

By 18 March 18167 confirmed COVID-19 cases (101 residents, 50 HCWs, 16 visitors) epidemiologically linked to the facility. Hospitalisation rates for COVID-19 positive residents: $54.5 \%$, visitors $50.0 \%$, staff $6.0 \%$; 34 deaths in the 101 residents and one in a visitor.

National point-prevalence COVID-19 testing programme in Ireland: residents and staff conducted 18 April to 5 May 2020 in all nursing homes and then if a new Kennelly 2021 [23] COVID-19 case was discovered every two weeks. For 45 nursing homes in Dublin and eastern Ireland complete surveys received from 28 homes (62.2\%) for 2043 residents.

Retrospective cohort study in $\mathbf{5}$ hospitals: 832 consecutive COVID-19 admissions 4 March to 24 April 2020, five hospitals Maryland and Washington, DC.

\section{Progression of epidemic: First} laboratory-confirmed community COVID-19 case in Ireland 29 February 2020. In the national survey the confirmed COVID-19 rate for residents $40.8 \%$ ( $25 \%$ asymptomatic); case fatality rate $25.8 \%$; for staff confirmed rate $33.6 \%$ within the first 28 days of an outbreak and $28.9 \%$ subsequently $(27.6 \%$ asymptomatic).

Progression to more severe COVID-19: 787 admitted with mild to moderate disease, 45 with severe disease (WHO scale) [23]. At discharge 523 (63\%) had experienced mild to moderate disease, $171(20 \%)$ severe disease and $131(16 \%)$ died. Progression to severe disease or death rapid and occurred in 181 $(60 \%)$ by day 2 and 238 (79\%) by day 4 . Progression to severe disease or death correlated with BMI, respiratory symptoms, respiratory rate, $\mathrm{C}$-reactive protein (CRP) level, albumin level, and temperature $>38.0^{\circ} \mathrm{C}$ and for those 60 to 74 years a detectable troponin level.

Older age and nursing home residence were associated with high comorbidity levels and risk of death. 
Table 4. Cont.

\begin{tabular}{|c|c|c|}
\hline \multicolumn{3}{|c|}{ Infections and Respiratory Infections in LTCFs and Nursing Homes } \\
\hline Author, Date & Setting & Disabilities and Mortality Rates \\
\hline Telle 2021 [26] & $\begin{array}{l}\text { National study in Norway: all } \\
8569 \text { individuals who tested positive for } \\
\text { SARS-CoV-2 by end of June } 2020 \text {. }\end{array}$ & $\begin{array}{l}\text { Outcomes for } \geq 90 \text { year olds compared to } \\
<50 \text { year olds: risks of hospitalisation } \\
(\mathrm{RR}=9.5 ; 7.1,12.7) \text { and death }(\mathrm{RR}=607.9 ; \\
145.5,2540.1) \text { much higher and risk of death } \\
\text { for nursing home residents was higher } \\
(\mathrm{RR}=4.2 ; 3.1,5.7)\end{array}$ \\
\hline Tarteret 2020 [27] & $\begin{array}{l}\text { Comparison of } 3 \text { nursing homes in France: } \\
2 \text { hospital-dependent nursing homes in } \\
\text { France with permanent physicians and } \\
\text { connections with infection prevention and } \\
\text { control departments and a nursing home } \\
\text { without permanent physicians, infection } \\
\text { control practitioner home or direct } \\
\text { connection with a general hospital. }\end{array}$ & $\begin{array}{l}\text { Mortality rates: During first } 3 \text { months of the } \\
\text { COVID-19 outbreak } 224 / 375(59.7 \%) \\
\text { residents classified as COVID-19 and } 57 / 375 \\
(15.2 \%) \text { died with rates of } 6.6 \% \text { in the } \\
\text { hospital-dependent homes and } 25.8 \% \text { in the } \\
\text { non-hospital-dependent home, OR }=0.20 \\
(0.11,0.38 ; p=0.001) \text {. } \\
\text { Risk factors for mortality: in COVID- } 19 \\
\text { patients during first } 3 \text { weeks of outbreak } \\
\text { lower if received a daily clinical examination } \\
\text { OR }=0.09(0.03,0.35 ; p=0.01) \text {, three vital } \\
\text { signs measured daily OR }=0.06(0.01,0.30 ; \\
p=0.001) \text { and prophylactic anticoagulation } \\
\text { OR }=0(0.00,0.24 ; p=0.001) .\end{array}$ \\
\hline Gopal 2021 [28] & $\begin{array}{l}\text { COVID-19 outbreak sizes in } 713 \text { LCTFs: } \\
\text { California to } 1 \text { May } 2020 .\end{array}$ & $\begin{array}{l}\text { Outbreak sizes: } 12.7 \text { times larger in } \\
\text { for-profit than non-profit LCTFs }(p<.001) \text {. } \\
\text { Higher ratings for approved Centers for } \\
\text { Medicare and Medicaid services correlated } \\
\text { with fewer infections in residents }(p<0.001) \\
\text { and staff }(p<0.05) \text {. }\end{array}$ \\
\hline Castriotta 2020 [29] & $\begin{array}{l}\text { Community COVID-19 mortality rates in } \\
\text { Italy: Friuli Venezia Giulia region, northern } \\
\text { Italy. }\end{array}$ & $\begin{array}{l}\text { COVID-19 mortality rates higher in older } \\
\text { seniors: for those } 70-79 \text { SMR }=16.13(95 \% \mathrm{CI} \\
9.73,26.74) \text { and for those } \geq 80 \text { SMR }=35.58 \\
(95 \% \text { CI } 21.77,58.15) \text { compared to those }<70 \\
\text { years. No significant differential mortality for } \\
\text { seniors in nursing homes. } \\
\text { Mortality variations between provinces: } \\
\text { Standardised mortality rates as of } 23 \text { June } \\
2020 \text { varied from high of } 2.92 \text { ( } 95 \% \text { CI } 2.88 \text {, } \\
2.97) \text { in Lombardia, and } 1.95 \text { ( } 95 \% \text { CI } 1.64, \\
3.30) \text { in Valle D'Aosta to a low of } 0.71(95 \% \text { CI } \\
0.68,0.74) \text { in Veneto, and in central Italy } \\
\text { SMR = } 0.13 \text { (95\% CI 0.11, } 0.17) \text { in Umbria and } \\
0.26(95 \% \text { CI } 0.24,0.28) \text { in Lazio, with } \\
\text { unexplained local transmission patterns. }\end{array}$ \\
\hline
\end{tabular}

3.3. Rates of Community Acquired Pneumococcal Pneumonia (CAP) and Invasive Pneumococcal Disease (IPD) in Seniors in the Community and in Nursing Homes and LCTFS

The prevalence of pneumococcal disease has been dramatically reduced in children after vaccination with PCV vaccines was implemented but remains substantial in seniors. In the US, in 2019 there were an estimated 502,600 nonbacteremic CAP cases, 29,500 IPD cases and 25,400 pneumococcal-related deaths among the 91.5 million adults $>50$ years [30].

Rates of pneumococcal disease for the UK 1990-2015 were assessed by a systematic review of 38 prospective, retrospective, registry and surveillance cohorts based on patients admitted to hospital (no studies of outpatients were identified). In 2013/14, the rate of community acquired pneumonia (CAP) and non-invasive disease was 20.6/100,000 adults, and for invasive pneumococcal invasive disease (IPD) it was 6.85/100,000 for all adult 
age groups and 20.58/100,000 for those $>65$. There were approximately 192,281 hospital admissions for pneumonia and 6000 cases of IPD in the UK in 2013/14 [31].

The incidence of pneumococcal disease in seniors is increased by several risk factors. A survey in UK general practice in 2009 estimated that in patients $\geq 65$ with no risk factors, the incidence of CAP was $17.9 / 100,000$, for the $44.8 \%$ of patients $\geq 65$ who had at least one risk factor 48/100,000, for the risk factor of Chronic Obstructive Pulmonary Disease (COPD) 91/100,000, and for chronic liver disease 129/100,000. Several serotypes had high fatality rates for those $\geq 65: 3(39 \%), 31(40 \%)$, and $19 \mathrm{~F}(41 \%)$ [32].

In the UK, the pneumococcal polysaccharide vaccine (PPV23) was authorised for patients $\geq 80$ in 2003, $\geq 75$ in 2004/5 and $\geq 65$ in 2005/6. For children, the first pneumococcal conjugate vaccine PCV7 was introduced in 2007 and PCV13 in 2010. After the introduction of the PCV vaccines for children, there was a beneficial herd protection effect on rates of pneumococcal diseases in seniors. For those $>65$ years, in 2008-10 the incidence of PCV13 IPD serotypes was 10.33/100,000 and declined to 3.72/100,000 in 2013/14 [33].

There is no single document which provides world-wide pneumococcal vaccination rates through 2019 for those $\geq 65$. Pneumococcal vaccination rates in those $\geq 65$ are suboptimal. In 2015 , in the US the vaccination rate was $60.2 \%$ for those $65-74,68.6 \%$ for $75-84$ and $68.3 \%$ for $85+; 41.7 \%$ for Hispanics, $68.1 \%$ for non-Hispanic whites, 50.2 for non-Hispanic Blacks, $49 \%$ for non-Hispanic Asians; and $48.7 \%$ for poor and $66 \%$ for non-poor individuals (CDC poor and non-poor classification) [34].

A retrospective cohort of $>26$ million US Medicare fee-for-service patients $\geq 652015$ 2017 is one of the few studies that provides a detailed listing by quintiles of vaccination rates for those $\geq 65$ to $100+$. Pneumococcal vaccination rates were: $65-69(47.5 \%), 70-74$ (49.7\%), 75-79 (49.7\%), 80-84 (48.1\%), 85-89 (45.5\%), 90-94 (39.7\%), 95-99 (32.5\%), and 100+ $(15.1 \%)$ [17]. For US nursing homes, the Minimum Data Set of the US Centers for Medicare and Medicaid Services reported pneumococcal vaccination coverage increased from $67.4 \%$ in 2006 to $78.4 \%$ in 2014, but there were large variations in pneumococcal vaccination coverage by state in 2014 (55.0\% to $89.7 \%$ ) [18].

For U.S. nursing home residents influenza and pneumococcal vaccination coverage increased from 2005 to 2015 but did not achieve the $90 \%$ national target for both vaccines and non-Hispanic black and Hispanic residents had lower vaccination rates [35]. A retrospective population-based observational study in January 2017 of 2,057,656 individuals $\geq 50$ years old in primary care centres in Catalonia, Spain, found large variations by age in the percentages vaccinated: 796,879 (38.7\%) had received PPV23, and of these $9.2 \%$ $(95,409 / 1,039,872)$ of $50-64$ year olds, $63.1 \%(434,408 / 688,786)$ of $65-79$ year olds and $81.2 \%$ $(267,062 / 328,998)$ of $\geq 80$ year olds $(p<0.001)$. However, only $13,607(0.7 \%)$ had received PCV13 [36].

In a sample of 2,531,227 individuals $\geq 15$ years in the Shanghai Centers for Disease Control and Prevention information systems on chronic disease management, hospital records, and immunizations, $22.8 \%$ were vaccinated for pneumonia from January 2013 to July 2017 but only $0.4 \%$ for influenza during the 2016/17 influenza season [37].

A study of nearly 10,000 IPD cases in those 65 and older in England and Wales 20122016 found that PPV23 vaccination effectiveness was 27\% (95\% CI 17, 35) after adjusting for age, comorbidities and infection year. Vaccine effectiveness varied with the interval after vaccination, and was $41 \%(95 \%$ CI 23,54$)$ for those vaccinated within two years, $34 \%(15$, $48)$ for those vaccinated $2-4$ years previously, and $23 \%(95 \%$ CI 12,32$)$ for those vaccinated $\geq 5$ years previously. Vaccine effectiveness was $45 \%(95 \%$ CI 27,59$)$ in those with no risk factors, $25 \%(95 \%$ CI 11,37$)$ in high-risk immunocompetent patients and $13 \%(95 \%$ CI 9,30$)$ in the immunocompromised patients (difference $p=0.05$ ) [38]. 


\section{Results: Improving the Health Status and Outcomes of Patients in LTCFs \\ 4.1. Interventions to Increase Vaccination Rates in Seniors and HCWs}

A systematic review identified 61 RCTs of interventions to increase community influenza vaccination rates. Most interventions focused on increasing demand from individuals by contacting them with letters or postcards and the most successful ones had a personal component consisting of a phone call by a receptionist or nurse. Interventions to make vaccines more available through home or group patient visits were also successful. Interventions paying physicians, competitions between physicians and benchmarking physicians' vaccination rates to those of the top $10 \%$ of vaccinators were also successful [39] (Table 5). An RCT in 823 nursing homes in the US used high-dose vaccinations to compensate for the waning of immunocompetence in seniors and found that the relative risk of influenza was reduced with high-dose vaccinations (adjusted relative risk $(R R)=0.873$; 95\% CI 0.776, 0.982; $p=0.023$ ) [40].

National vaccination programmes are an important stimulus to increase community pneumococcal vaccination rates [41,42], but rates still remain below national targets for seniors. Even after campaigns with subsidised vaccination in Japan, the national rate was only 74\%. In England, the coverage of PPV23 in those $\geq 65$ was similar to Japan at $70.1 \%$ in 2015 and 69.5\% in 2018 [43]. In Australia, after public funding for PPV23 commenced in 2005, the vaccination rate increased from 35.4\% before 2005 to $56.0 \%$ after 2005 [44]. In South Korea, during a 20 -month national immunisation program the pneumococcal vaccine rate for $\geq 65$ years increased from $5.0 \%$ to $57.3 \%$ [45].

Table 5. Interventions to increase influenza and pneumococcal vaccination rates in seniors and in HCWs.

\begin{tabular}{|c|c|c|c|}
\hline Author, Date & Setting & Interventions & Outcomes or Observations \\
\hline Thomas 2018 [39] & $\begin{array}{l}\text { Systematic review of } 61 \text { RCTs to } \\
\text { increase influenza vaccination } \\
\text { rates in } \geq 60 \text { years }\end{array}$ & $\begin{array}{l}\text { (1) Increase demand from } \\
\text { individuals, (2) increase vaccine } \\
\text { access, (3) increase provision. } \\
38 \% \text { of RCTs assessed low risk of } \\
\text { bias for randomisation, } 11 \% \\
\text { allocation concealment, } 44 \% \\
\text { blinding, } 51 \% \text { missing data, } 0 \% \\
\text { selective reporting; overall } \\
\text { evidence low quality. }\end{array}$ & 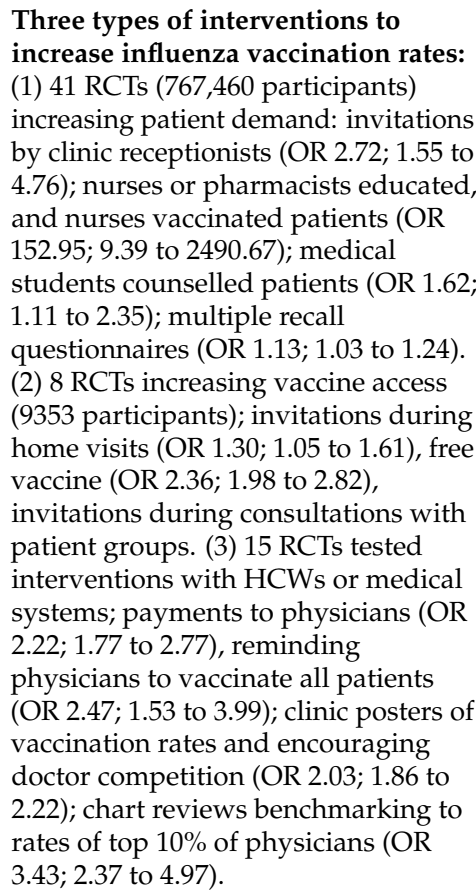 \\
\hline
\end{tabular}


Table 5. Cont.

\begin{tabular}{|c|c|c|c|}
\hline Author, Date & Setting & Interventions & Outcomes or Observations \\
\hline Gravenstein 2017 [40] & $\begin{array}{l}823 \text { nursing homes in USA, } \\
\text { Medicare-certified } \\
\text { (92,269 residents; } \\
75,917 \geq 65 \text { years) }\end{array}$ & $\begin{array}{l}409 \text { homes randomised to } \\
\text { high-dose influenza vaccination, } \\
414 \text { homes to standard-dose } \\
\text { vaccine }\end{array}$ & $\begin{array}{l}\text { Respiratory-related hospital } \\
\text { admissions rate: significantly lower } \\
(3.4 \% \text { over } 6 \text { months) in homes whose } \\
\text { residents received high-dose influenza } \\
\text { vaccines vs. } 3.9 \% \text { in standard-dose } \\
\text { influenza vaccines; adjusted } \\
(R R)=0.873(0.776 \text { to } 0.982 ; p=0.023) \text {. }\end{array}$ \\
\hline
\end{tabular}

Interventions to Increase Seniors' Pneumococcal Vaccination Rates

$\begin{array}{ll}\begin{array}{l}\text { Japan, national vaccination } \\ \text { campaign, 2014 }\end{array} & \begin{array}{l}\text { Public subsidy for } \\ \text { pneumococcal vaccination }\end{array} \\ & \text { (PPV23) for } \geq 65 \text { years }\end{array}$

Naito 2020 [41]

Japanese Health Ministry survey

influenza vaccine coverage all

municipalities $(n=1741) ; 1010$

municipalities $(58.0 \%)$ responded
Direct mail offer of subsidised PPV23 vaccination (n)

Vaccination rates: $0 \%$ in $2009,10 \%$ in

$2011,40.6 \%$ after campaign in 2015 ,

$74 \%$ 2018. Child vaccination programme included PCV7 then PCV13 resulting in increase in community prevalence of serotypes 8 , $9 \mathrm{~N}$ and $12 \mathrm{~F}$ (which comprise $40 \%$ of serotypes causing Invasive Pneumococcal Disease (IPD) in elderly). However, these serotypes are included in PPV23 which thus provides protection to elderly.

Median PPV23 coverage for $\geq 65$ years for responding municipalities 2016 $41.8 \%$.

Differences in response rates: $18.7 \%$ higher in municipalities which sent direct mail notification to targeted adults. Rate decreased by $3.02 \%$ for every $¥ 1000$ increase in out-of-pocket costs to individuals and coverage inversely related to municipality unemployment rates and average per capita income.

\section{Interventions to Increase Influenza Vaccination Rates of Health Care Workers in LCTFs}

Systematic review of four
c-RCTs and one cohort study
$(n=12,742)$ of influenza
vaccination for HCWs caring for
individuals $\geq 60$ years of age in
LTCFs. Studies similar in study
populations, interventions and
outcome measures [48-51].

Systematic review of four $(n=12,742)$ of influenza vaccination for HCWs caring for LTCFs. Studies similar in study outcome measures [48-51]. Vaccination offered to residents
and HCWs in intervention arms and usual care in control arms. Bias in studies due to attrition, lack of blinding, contamination in control groups and low rates of vaccination coverage in intervention arms. GRADE quality assessments downgraded for all outcomes due to serious risk of bias.
Laboratory-proven influenza: $\mathrm{HCW}$ influenza vaccination in LTCFs may have little or no effect on number of residents who develop compared with those living in care homes where no vaccination offered (RD 0 (95\% CI -0.03 to 0.03 )) (2 studies, 752 participants; low quality evidence); Lower respiratory tract infection: HCW vaccination probably leads to reduction in residents from $6 \%$ to $4 \%$ (RD - 0.02 (95\% CI - 0.04 to 0.01)) (one study, $n=3400$ people, moderate quality evidence);

Number of residents admitted to hospital for respiratory illness: HCW vaccination programmes may have little or no effect on (RD $0(95 \%$ CI -0.02 to 0.02 )) (one study $n=1059$; low quality evidence). Deaths from lower respiratory tract infection: Data not combined (two studies, $n=4459$ ) or all cause deaths (four studies, $n=8468)$. Very low quality of evidence because direction and size of difference in risk varied between studies and uncertainty about the effect of vaccination on these outcomes. 
The WHO is supporting interventions to vaccinate all citizens in all countries against SARS-CoV-2 with the multibillion COVAX vaccine sharing programme, with the additional purpose of limiting the emergence of more variants. Seniors and front-line health workers have been prioritised in all WHO regions for SARS-CoV-2 vaccination. The duration of antibodies is uncertain and seniors will need to be monitored for antibody levels and the interval to optimum revaccination assessed. SARS-CoV-2 may require annual revaccination like influenza and shorter revaccination intervals may emerge especially with the emergence of more variants. SARS-CoV-2 and increasingly its variants will likely become an integral component of the respiratory infections that present major risks for mortality.

Finland is the only country which has made influenza vaccination compulsory for HCWs, on the analogy that multiple vaccinations are required (e.g., measles, mumps, hepatitis A and B ... ) to work in hospitals and clinics. The hesitancy of HCWs in other countries is based on the paucity of evidence and the reluctance of HCWs to be vaccinated (the reasons most frequently provided are lack of confidence in the effectiveness of the vaccine, concern for side-effects, dislike of needles and belief they are not at risk).

A Cochrane collaboration systematic review of vaccinating HCWs against influenza who care for seniors in nursing homes and LTCFs [46,47] identified only four c-RCTs [48-51] and did not show convincing evidence of benefit for patients for laboratory-proven influenza (low quality evidence), lower respiratory tract infections (moderate quality evidence), admissions to hospital (low quality evidence), or deaths from lower respiratory tract illness or from all causes (very low-quality evidence). The Hayward c-RCT [50] was excluded from the computations in later editions of the Cochrane review [47] because it used influenzalike illness (ILI) as the outcome measure and a systematic review of all studies showed that less than $25 \%$ of all patients identified by physicians as ILI had a positive laboratory test for influenza [52]. No c-RCTs have been published subsequently. The authors of the Cochrane review concluded that large well-conducted c-RCTs were needed with arms which also measured the effects of face masks, handwashing and high vaccination rates of HCWs [47]. The effects of social distancing should now also be added. The thoroughness of the implementation of each of these preventive measures would be essential to the success of the c-RCTs in providing evidence of high quality [53]. A systematic review identified 46 studies of interventions to increase influenza vaccination rates in HCWs but conducted a meta-analysis incorrectly pooling the nine c-RCTs, two RCTs and 35 beforeand-after studies together. Of the c-RCTs, eight had unclear randomisation, five no baseline vaccination rates and six incomplete data, and the review does not provide pooled data at low risk of bias [54].

Subsequent authors have agreed with the assessment of the Cochrane reviews. The article by De Serres [55] also focused on the inappropriateness of ILI and all-cause mortality as outcome measures and the implausible greater reductions in influenza for less influenzaspecific outcomes:

"In attributing patient benefit to increased HCW influenza vaccine coverage, each cRCT was found to violate the basic mathematical principle of dilution by reporting greater percentage reductions with less influenza-specific patient outcomes (i.e., all-cause mortality $>$ ILI > laboratory-confirmed influenza) and/or patient mortality reductions exceeding even favourably derived predicted values by at least 6- to 15-fold." [55], p. 2. Nevertheless, the authors also concluded: "Although current scientific data are inadequate to support the ethical implementation of enforced HCW influenza vaccination, they do not refute approaches to support voluntary vaccination or other more broadly protective practices, such as staying home or masking when acutely ill." [55], p. 2.

Similarly, an "Expert Commentary" article assessing the WHO guidelines for the prevention of influenza in LTCs [56] commented:

"Although the currently available evidence may be weak for HCW vaccination to protect the frail and elderly, there is also generally no evidence against it. Therefore, it remains a biologically plausible intervention to provide individual protection to the $\mathrm{HCW}$, act as a barrier against spread of infection and to help reduce the risk associated with 
influenza infection and prevent staff absenteeism. However, poor vaccine uptake by HCWs has been well documented. In Europe, coverage of HCWs (including those working in LTCFs) varies between countries and is generally much lower than for other vaccination targeted groups, ranging from $9.5 \%$ to $75 \%$ with a median vaccination coverage rate of $28.6 \%$. In the United States, vaccination rates of $50-70 \%$ have been reported for LTCF workers, with coverage consistently lower than among staff working in hospital settings. Reasons given for declining vaccination include fear of side effects, lack of concern or perception of risk, doubts about vaccine efficacy, lack of availability or inconvenient delivery of vaccine, avoidance of medications and dislike of injections. Although mandatory vaccination is effective if it can be implemented, it is not legally enforceable in all countries and settings, and infection rates after the implementation of mandatory vaccination have not been studied." [57].

Behaviour theories have been used to predict HCW influenza vaccination rates and a review of ten studies assessed them at moderate risk of bias due to self-report of vaccination and non-representative samples. Five studies used either the Health Belief Model, the Theory of Planned Behavior, the Risk Perception Attitude, or the Triandis Model of Interpersonal Behavior, which measured attitudes about the efficacy and safety of influenza vaccination, risk and benefit perceptions for the HCW and others, cues for action, and social-professional norms. These factors and sociodemographic variables predicted $85-95 \%$ of HCW influenza vaccination uptake. Vaccination in previous years was an important predictor. RCTs comparing the outcomes for patients of interventions based on these theories, mandatory vaccination policies and HCW remuneration for vaccination are needed [58].

\subsection{Implementation of Comprehensive Infection Control Policies for COVID-19 in Nursing Homes} and LTCFs

The effectiveness of comprehensive infection control strategies for respiratory infections in nursing homes and LTCFs has been best illustrated for COVID-19. The CDC has published specific recommendations for assessing the signs and symptoms of SARS-CoV-2 and influenza in nursing homes and LTCFs [59] (Table 6).

Table 6. CDC recommendations for nursing home residents with acute respiratory illness symptoms when SARS-CoV-2 and influenza viruses are circulating.

$>$ Ask all residents daily if they have respiratory illness symptoms, daily temperatures, any signs or symptoms.

$>$ Test for SARS-CoV-2 by nucleic acid detection OR by SARS-CoV-2 antigen detection assay (lower sensitivity) so confirm antigen test with SARS-CoV-2 nucleic acid detection assay.

If a new SARS-CoV-2 infection is identified in a nursing home promptly test all residents.

$>$ Test for influenza by rapid influenza nucleic acid detection assay OR rapid influenza antigen detection assay (lower sensitivity) so confirm antigen test with influenza nucleic acid detection assay.

For symptomatic residents use all recommended PPE with suspected SARS-CoV-2 infection, move to a single room, no new roommates, move to the COVID-19 care unit when confirmed by SARS-CoV-2 testing.

$>$ Promptly notify health department for further investigation of suspected or confirmed case of SARS-CoV-2 or influenza in a resident or a healthcare person, a resident with severe respiratory infection resulting in hospitalization or death; or $\geq 3$ residents or HCP with new-onset respiratory symptoms within 72 hours of each other.

$>$ Move all residents with confirmed SARS-CoV-2 infection to a dedicated COVID-19 care unit.

$>$ Residents found to have SARS-CoV-2 and influenza virus co-infection should be placed in a single room on the dedicated COVID-19 unit or housed with other co-infected residents on that unit. These residents should continue to be cared for using all recommended PPE for the care of a resident with SARS-CoV-2 infection.

$>$ Place residents with confirmed influenza in a single room, or with other residents with only influenza, and if unable to move resident, use measures to reduce transmission to roommates (e.g., physical barriers, antiviral chemoprophylaxis) and droplet precautions. 
The CDC provides a guide to assessing COVID-19 and influenza signs and symptoms which can be used as an initial guide to decide risks and thus testing and isolation management, but the CDC noted the considerable similarities in symptoms [60]. The WHO has published public health advice which is more general in scope about controlling SARS-CoV-2 infections in the community, which is the reservoir for infections in nursing homes and LTCFs [61].

Two key problems in managing SARS-CoV-2 infections are the high rate of asymptomatic or minimally symptomatic patients and which management decisions to make if initial laboratory tests are negative. Prompt diagnosis of whether patients have SARSCoV-2 permits isolation or discharge to free up clinical resources for other patients. In hospitals in Boston, Massachusetts, 2443/3358 (73\%) inpatients were assessed as possibly SARS-CoV-2 but had a negative nucleic acid amplification test (NAAT). The CORAL tool (COvid Risk cALculator) uses structured entry of clinical data, and after its use there were significant reductions in patients detained for repeat SARS-CoV-2 nucleic acid amplification tests (NAATs) ( $54 \%$ vs. $67 \%$; aOR $0.53,95 \%$ CI: $0.44-0.63, p<0.01)$, the duration of potentially infected status (adjusted difference: -19.5 (SE 1.9) hours/patient; $p<0.01$ ) and average infectious disease physicians' work-hours (adjusted difference: -57.4 (SE 2.0) hours/day; $p<0.01$ ). After CORAL advised the discontinuation of precautions, no patient had a positive NAAT within the next seven 7 days [62].

The importance of comprehensive testing to identify asymptomatic cases has been demonstrated in several studies (Table 7). In Catalonia, Spain, daily monitoring for COVID19 with a COVIDApp of 10,347 patients and $\sim 4000$ HCWs in 196 care centers identified a large number, 5090/10,347 (49\%), of asymptomatic patients. There were $854(8.3 \%)$ deaths (of which $44.8 \%$ were either suspected or confirmed COVID-19 cases), the number of high-risk long-term care facilities decreased from 19/196 (9.5\%) to 3/196 (1.5\%) but the number of HCWs with suspected COVID-19 remained $\sim 1000$ and the number isolated at home varied between 400 and 600 [63]. In 11 LTCFs in Maryland, USA, after the index case the public health department identified 153 cases within the next 20 days. In a subsequent study, all 893 untested residents were tested and an additional 354 (39.6\%) tested positive for SARS-CoV-2, of whom 281 (55.4) were asymptomatic (symptoms were defined as any fever $>99^{\circ} \mathrm{F}$, cough, diarrhea, respiratory decompensation, or other acute clinical status changes) [64].

Rapid and comprehensive responses to SARS-CoV-2 have been reported by several LCTFs. The key interventions are daily comprehensive monitoring of all residents, staff and visitors for symptoms and contacts using the CDC tools $[65,66]$, and if risks are detected prompt testing using nucleic acid detection or SARS-CoV-2 antigen detection assay. As the antigen test has a lower sensitivity, confirmation of the antigen test with the SARS-CoV-2 nucleic acid detection assay is required. Due to the high rate of asymptomatic individuals, it is important to prevent admissions from institutions or communities with SARS-CoV-2 cases. Comprehensive training of staff in hand sanitation, surface sanitation, PPE (masks, eye protection, gloves, waterproof gowns) and social distancing and furloughing infected or potentially infected staff are crucial. It is important that a team of infectious disease specialists and infection preventionists closely monitors the situation daily and ensures preventive measures are followed and resources are provided promptly. Examples are the strategies of the US Veterans Affairs Midwest network, which used seven strategies to avoid the admission of SARS-CoV-2 patients and reported no positive RT-PCR SARS-CoV-2 tests from 6 March through 1 September 2020 [67]. In British Columbia, Canada, 75 LTCFs used eight strategies to minimise SARS-CoV-2 admissions and transmission within homes and there was a $32 \%$ reduction in cases [68]. In Georgia, USA, 24 LTCFs used the comprehensive set of CDC COVID-19 indicators to identify why COVID-19 rates differed between high (62\% infection rate) and low prevalence (15\% infection rate) homes [69]. In 17 nursing homes in France, 794 staff voluntarily confined themselves to their facilities with their 1250 residents, and COVID-19 was identified in only 5 residents $(0.4 \%)$ compared to 30,569 $(4.44 \%)$ in a national survey of 9513 homes [70] (Table 8). 
Reducing the effect of crowding on increasing rates by providing patients with single rooms is important. For 618 nursing homes in Ontario, Canada, in homes with a low crowding index COVID-19 incidence was $4.5 \%$ and in high crowding homes $9.6 \%$, and COVID-19 mortality was $1.3 \%$ and $2.7 \%$ [71]. Crowding in the community also increases the risk of admitting infected patients. The effects of community crowding were demonstrated in a study of the 175 postal zip codes in New York. Average household size independently explained $62 \%$ of the variation in COVID-19 rates. Rates were higher in those zip codes with higher percentages of individuals $\geq 65$ or living below the poverty line, African Americans and Hispanics. Housing density in itself was not a predictor of COVID-19 rates [72].

Table 7. Preventive COVID-19 interventions and outcomes in LTCFs.

\begin{tabular}{|c|c|c|}
\hline Author, Date & Setting & Interventions \\
\hline Goto 2021 [67] & $\begin{array}{l}\text { US Veterans' Affairs Midwest } \\
\text { HealthCare Network }\end{array}$ & $\begin{array}{l}\text { (1) Admit patients from hospitals or } \\
\text { communities with no COVID-19 cases. } \\
\text { (2) Quarantine admissions in } \\
\text { single-patient rooms } 14 \text { days. (3) Daily } \\
\text { screening for temperature, symptoms. } \\
\text { (4) Only visitors critical to care-giving. } \\
\text { (5) No temporary staff. (6) Hand and } \\
\text { respiratory education. (7) Supervised } \\
\text { by full-time infection on-site } \\
\text { preventionists and infectious disease } \\
\text { specialists. }\end{array}$ \\
\hline
\end{tabular}

75 LTCFs in British Columbia (1) Symptom assessment, testing all

Vijh 2021 [68]

24 LTCFs, Fulton County, Georgia, which had $85 \%$ of COVID-19 positive residents of Telford 2020 [69] all LTCFs in the county

\section{CDC COVID-19 tool indicators} assessed prevalence $[59,60]$ : 11 LTCFs with higher prevalence: (1310 residents, 817 cases) average infection rate $62 \%$ (range 46-74\%), 196 hospitalisations, 124 deaths. 13 LCTFs with lower prevalence: (1270 residents, 187 cases) average infection rate $15 \%$ (range $1-33 \%$ ), 51 hospitalisations, 38 deaths.

17 nursing homes in France compared to national survey of 9513 LTCFs (385,290 staff; 695,060 residents)

17 nursing homes in which 794 staff members voluntarily confined themselves to the facility with their 1250 residents. residents and staff; contact tracing; isolation of high risks. (2) Universal personal protective equipment (PPE) all staff; contact and droplet precautions all COVID-19 cases (confirmed, suspected or exposed) and residents with significant exposure. (3) COVID-19 mobile team provided assessment and education. (4) No admissions or community discharges. (5) Residents restricted to rooms; staff cohorted to wards; COVID-19 residents cohorted to rooms. (6) Enhanced cleaning rooms, common spaces, high-touch surfaces. (7) Check-in with staff provision additional staff/resources. Daily

Outcomes or Observations

Minimal COVID-19 infections: All residents from 6 March to 1 September 2020 reverse-transcriptase polymerase chain reaction (RT-PCR) for SARS-CoV-2 negative; 4 employees positive and asymptomatic and furloughed.

Initial outbreak: 28 February to 30 May 2020, $18(24 \%)$ LTCFs had at least 1 documented exposure from a COVID-19 case (total $n=165$ staff and 110 residents). During the two weeks after outbreak significant increase in COVID-19 incidence $\mathrm{RR}=1.07$ (1.03 to $1.11 ; p<0.001$ ).

Results 14 days and onwards after interventions were implemented: significant decrease in cases $\mathrm{RR}=0.68$ ( 0.62 to $0.75 ; p<0.001$ ) and $27 \%$ decrease in incidence rate every 2 days $R R=0.73$ (0.67 to $0.80 ; p<0.001$ ).

Prevention implementation in lower COVID-19 prevalence LTCFs compared to higher prevalence LTCFs: $69 \%$ implementation of hand hygiene indicators $(55 \%$ in higher prevalence group), $77 \%$ disinfection indicators (36\%), $74 \%$ social distancing indicators $(54 \%)$, personal protective equipment indicators $72 \%(41 \%), 82 \%$ screening indicators (64\%).
17 nursing homes in which staff confined themselves with patients: $1 / 17(5.8 \%)$ homes had $5(0.4 \%)$

COVID-19 resident cases; $5(0.4 \%)$ deaths; confirmed or possible COVID-19 in $12(1.6 \%)$ staff members.

National survey of nursing homes: 30,569 (4.4\%) COVID-19 resident cases $(p<0.001)$; self-confinement of 31,799 $(4.6 \%)$ residents; $12,516(1.8 \%)$ resident deaths $(\mathrm{OR}=0.22$ (95\% CI 0.09 to 0.53 ; $p<0.001$ ); confirmed or possible COVID-19 in 29,463 staff members $(7.6 \%)(p<0.001)$. 
Table 7. Cont.

\begin{tabular}{|c|c|c|c|}
\hline Author, Date & Setting & Interventions & Outcomes or Observations \\
\hline Brown 2021 [71] & $\begin{array}{l}\mathbf{6 1 8} \text { nursing homes Ontario, } \\
\text { Canada }(78,607 \text { residents })=99 \% \\
\text { of all } 623 \text { homes }\end{array}$ & $\begin{array}{l}\text { Assessment of effect of crowding } \\
\text { (crowding index assessed } \\
\text { single-bedded to four-bedded rooms). }\end{array}$ & $\begin{array}{l}29 \text { March to } 20 \text { May } 20205218(6.6 \%) \\
\text { residents developed COVID-19 } \\
\text { infection; } 4496(86 \%) \text { of infections } \\
\text { occurred in only } 63(10 \%) \text { homes; } 1452 \\
(1.8 \%) \text { residents died of COVID-19 } \\
\text { infection to May } 202020 \text {. } \\
\text { Low crowding index homes: } \\
\text { COVID-19 incidence } 4.5 \% \text {; mortality } \\
1.3 \% \text {. } \\
\text { High crowding index homes: } \\
\text { COVID-19 incidence } 9.7 \%(p<0.001) \text {, } \\
\text { mortality } 2.7 \% ;(p<0.001) .\end{array}$ \\
\hline Jones 2021 [73] & 623 LCTFs in Ontario, Canada & $\begin{array}{l}\text { Policy to prevent staff working in } \\
\text { multiple LTCFs }\end{array}$ & $\begin{array}{l}\text { Before policy: } 266(42.7 \%) \text { homes had } \\
\text { staff working in at least } 1 \text { other home. } \\
\text { After policy instituted: } 79(12.7 \%) \\
\text { homes had staff working in } 1 \text { other } \\
\text { home (decrease } 70.3 \%(p<0.001)) \text {; } \\
\text { average number of connections between } \\
\text { homes declined } 3.90 \text { to } 0.77 \text { (decrease of } \\
80.3 \%, p<0.001)\end{array}$ \\
\hline
\end{tabular}

Preventing staff working in multiple homes reduces COVID-19 rates. In 623 LTCFs in Ontario, Canada, before a policy was introduced to prevent multiple site working, 266 (42.7\%) homes had staff working in at least one other home, and after the policy was instituted $79(12.7 \%)$ had staff working in at least one other home, and the average number of connections between homes declined from 3.90 to $0.77(p<0.001)$ [73].

It is also important to identify which patients with SARS-CoV-2 are at high risk of poor outcomes and death.

A study in 351 US nursing homes of 5256 residents with severe acute respiratory syndrome SARS-CoV-2 found that compared to those 75 to 79 years, the all-cause mortality rate within 30 days increased with higher ages: for those 80 to 84 years OR $=1.46$ (1.14 to 1.86), for those 85 to 89 years $\mathrm{OR}=1.59$ (1.25 to 2.03) and for those $\geq 90 \mathrm{OR}=2.14$ (1.70 to 2.69). Four physical findings were related to a higher mortality risk: fever OR = 1.66 (1.41 to 1.96), shortness of breath OR $=2.52$ (2.00 to 3.16), tachycardia OR = 1.31 (1.04 to 1.64), and hypoxia $\mathrm{OR}=2.05$ (1.68 to 2.50$)$. Four co-morbidities were associated with an increased risk of mortality: diabetes $\mathrm{OR}=1.21$ (1.05 to 1.40$)$, chronic kidney disease OR = 1.33 (1.11 to 1.61), severe cognitive impairment $\mathrm{OR}=2.79$ (2.14 to 3.66), and severe impairment in physical function $\mathrm{OR}=1.64$ (1.30 to 2.08$)$ [74].

\subsection{Increasing the Use of Medical or Surgical Masks and Hand Hygiene to Reduce the Transmission of Respiratory Viruses}

The most comprehensive and recent systematic review of mask-wearing and hand hygiene is the Cochrane review by Jefferson et al. (2020), but it included no studies during the COVID-19 pandemic period [75]. In many studies, the risk of bias for the RCTs and c-RCTs was mostly high or unclear. The review included only three c-RCTs of hand hygiene in nursing homes. McConeghy's 2017 study [76] was assessed at unclear risk for random sequence generation and allocation concealment, high risk for blinding of personnel and participants, outcome assessment and selective reporting; Temime's 2018 study [77] was at high risk for random sequence generation, unclear risk from allocation concealment, high risk from blinding of participants and personnel, performance assessment and incomplete data; and Yeung's 2011 study [78] was at unclear risk from random sequence generation, allocation concealment and selective reporting and high risk from blinding of participants and personnel and outcome assessment. There is only one c-RCT of hand hygiene for patients and staff which assessed bacterial contamination and there was a significant decrease 
in bacterial colonisation [79]. A 2020 systematic review of hand washing, distancing and mask wearing to prevent the transmission of SARS-CoV-2 identified 172 observational studies in 16 countries but no RCTs, and a meta-analysis of 44 non-randomised studies identified substantial protection by distancing more than one metre, hand washing, mask wearing and eye protection [80] (Table 9).

Table 8. Interventions to decrease respiratory disease transmission using masks, hand washing, isolation rooms, decreasing surface contamination and identifying communities at risk.

\begin{tabular}{|c|c|c|c|}
\hline \multicolumn{4}{|c|}{ Interventions to Decrease Respiratory Disease Transmission Using Masks, Hand Washing, and Isolation } \\
\hline Author, Date & Setting & Interventions & Outcomes or Observations \\
\hline Jefferson 2020 [75] & $\begin{array}{l}\text { Hospital wards in high-income } \\
\text { countries, suburban schools, and } \\
\text { inner cities in low-income } \\
\text { countries. }\end{array}$ & $\begin{array}{l}\text { Comparison of medical or surgical } \\
\text { masks to no masks: } 8 \text { c-RCTs, } 1 \\
\text { RCT ( } 2 \text { trials with healthcare } \\
\text { workers and } 7 \text { in the community). }\end{array}$ & $\begin{array}{l}\text { Low certainty evidence mask } \\
\text { wearing may make little or no } \\
\text { difference in influenza-like illness } \\
\text { (ILI): compared to not wearing masks } \\
\mathrm{RR}=0.99(0.82,1.18 ; 6 \text { trials, } \\
3507 \text { participants). } \\
\text { Moderate certainty evidence mask } \\
\text { wearing probably makes little or no } \\
\text { difference to laboratory-confirmed } \\
\text { influenza: compared to not wearing } \\
\text { masks RR = } 0.91 \text { ( } 0.66,1.26 ; 6 \text { trials; } \\
3005 \text { participants). }\end{array}$ \\
\hline Jefferson 2020 [75] & $\begin{array}{l}\text { Comparison of respirators and } \\
\text { masks. }\end{array}$ & $\begin{array}{l}\text { Comparison of } \mathrm{N} 95 / \mathrm{P} 2 \text { respirators } \\
\text { to medical/surgical masks. }\end{array}$ & $\begin{array}{l}\text { Clinical respiratory illness: very low } \\
\text { certainty evidence: RR }=0.70(0.45, \\
1.10 ; 3 \text { trials; } 7779 \text { participants); } \\
\text { ILI: low-certainty evidence: due to } \\
\text { imprecision and heterogeneity } \\
\text { RR }=0.82(0.66,1.03 ; 5 \text { trials; } 8407 \\
\text { participants); } \\
\text { Laboratory-confirmed influenza: } \\
\text { little or no difference and } \\
\text { moderate-certainty evidence: } \\
\text { RR = } 1.10 \text { ( } 0.90,1.34 ; 5 \text { trials; } 8407 \\
\text { participants) with no differences for } \\
\text { health care workers (HCWs). }\end{array}$ \\
\hline Jefferson 2020 [75] & $\begin{array}{l}\text { Hand hygiene studies in schools, } \\
\text { childcare centres, homes, and } \\
\text { offices. }\end{array}$ & $\begin{array}{l}\text { Hand hygiene interventions } \\
\text { compared to no intervention. }\end{array}$ & $\begin{array}{l}\text { Acute respiratory infections (ARIs): } \\
\text { hand hygiene interventions compared } \\
\text { to no intervention: } 16 \% \text { relative } \\
\text { reduction in number of people with } \\
\text { RR }=0.84(0.82,0.86 ; 7 \text { trials; } \\
44,129 \text { participants; probable benefit } \\
\text { with moderate-certainty evidence); } \\
\text { ILI: RR = } 0.98 \text { ( } 0.85,1.13 ; 10 \text { trials; } \\
32,641 \text { participants; little or no } \\
\text { difference with low-certainty } \\
\text { evidence); } \\
\text { Laboratory-confirmed influenza: } \\
\text { RR = } 0.91 \text { ( } 0.63,1.30 ; 8 \text { trials; } \\
8332 \text { participants; little or no } \\
\text { difference with low-certainty } \\
\text { evidence). }\end{array}$ \\
\hline
\end{tabular}


Table 8. Cont.

Interventions to Decrease Respiratory Disease Transmission Using Masks, Hand Washing, and Isolation

\begin{tabular}{|c|c|c|c|}
\hline Author, Date & Setting & Interventions & Outcomes or Observations \\
\hline Cheng 2018 [79] & $\begin{array}{l}10 \text { residential care homes for the } \\
\text { elderly, Hong Kong. }\end{array}$ & $\begin{array}{l}5 \text { homes randomised to directly } \\
\text { observe hand hygiene (DOHH) of } \\
\text { residents' hands by hand hygiene } \\
\text { ambassador nurses, and } 5 \text { homes } \\
\text { randomised to usual care control } \\
\text { group. } \\
\text { Intervention: ( } 515 / 774 \text { residents } \\
\text { participated) hand cleaning by hand } \\
\text { hygiene ambassador nurse at } \\
\text { two-hourly intervals and also before } \\
\text { meals and medication rounds } 9 \text { am } \\
\text { to } 6 \text { pm weekdays; during } 8 \text {-week } \\
\text { intervention samples collected twice } \\
\text { weekly immediately before } \\
\text { environmental cleaning from } \\
\text { communal areas (blood pressure } \\
\text { cuff, meal table-top, activity } \\
\text { table-top, chair armrest, corridor } \\
\text { hand rail, remote TV control), and } \\
\text { in staff areas (station table top, } \\
\text { computer keyboard and mouse, } \\
\text { trolley-top and handle, telephone } \\
\text { handle). }\end{array}$ & $\begin{array}{l}\text { Baseline colonisation: } 33 \% \text { of } \\
100 \text { samples culture-positive for } \\
\text { methicillin-resistant Staphylococcus } \\
\text { aureus (MRSA); } 26 \% \text { of } 100 \text { specimens } \\
\text { for carbapenem-resistant Acinetobacter } \\
\text { species (CRA). } \\
\text { Serial monitoring of colonisation } \\
\text { during } 2 \text { month intervention: } \\
\text { MRSA: present in } 79 / 600 \text { (13.2\%) of } \\
\text { samples in intervention homes and in } \\
197 / 600 \text { ( } 32.8 \% \text {; } p<0.001 \text { ) in control } \\
\text { homes, and } \\
\text { CRA: present in } 56 / 600 \text { (9.3\%) of } \\
\text { samples in intervention homes and } \\
94 / 600 \text { (15.7\%; } p=0.001 \text { ) in control } \\
\text { homes. } \\
\text { Volume of Alcohol Based Hand Rub } \\
\text { (ABHR): consumed/resident/week } 3 \\
\text { times higher in intervention group } \\
\text { (59.3 } \pm 12.9 \text { mL) compared with } \\
\text { baseline (19.7 } \pm 12.6 \text { mL; } p<0.001) \\
\text { and significantly higher than in } \\
\text { control group ( } 23.3 \pm 17.2 \text { mL; } \\
p=0.006 \text { ). } \\
\text { Hand hygiene compliance: improved } \\
\text { from } 27 \% \text { to } 60 \% \text { during study period, } \\
\text { but adherence to WHO Five Moments } \\
\text { hand hygiene campaign not sustained, } \\
\text { and bacterial contamination occurred } \\
\text { with return from hospital care. }\end{array}$ \\
\hline
\end{tabular}

Systematic review of physical distancing, face masks and eye protection on spread of SARS-CoV-2.
Search of $21 \mathrm{WHO}$-specific and COVID-19 sources:

172 observational studies;

44 non-randomised studies selected for meta-analysis, no RCTs identified.
Chu 2020 [80]

\section{Virus transmission: Lower rates} with physical distancing $\geq 1$ metre: ( $n=10,736, \mathrm{OR}=0.18$ (0.09 to 0.38 ); risk difference (RD) $-10.2 \%$ ( -11.5 to -7.5 ; moderate certainty); Protection increased with distance $R R=2.02$ per metre ( $p=0.041)$; moderate certainty) Lower rates with face mask use: $(n=2647 ; \mathrm{OR}=0.15$ ( 0.07 to $0.34, \mathrm{RD}$ $-14.3 \%,-15.9$ to -10.7 ; low certainty)).

Lower rates with N95 or similar respirators compared with disposable surgical or cotton masks: $(p=0.090)$; low certainty. Lower rates with eye protection: $(n=3713 ; \mathrm{OR}=0.22$ (0.12 to $0.39, \mathrm{RD}$ $-10.6 \%, 95 \%$ CI -12.5 to -7.7 ; low certainty)).

Interventions and Models of Interventions to Isolate Infected Patients

\begin{tabular}{|c|c|c|c|}
\hline Author, Date & Setting & Interventions & Outcomes or Observations \\
\hline Kim 2020 [81] & $\begin{array}{l}\text { Emergency department, } \\
\text { Chungbuk National University } \\
\text { Hospital, Cheongju, South Korea. }\end{array}$ & $\begin{array}{l}27 \text { February to } 31 \text { March } 2020,2455 \\
\text { patients assessed for potential } \\
\text { COVID-19 and if fever or } \\
\text { respiratory symptoms they were } \\
\text { screened in triage room, and if } \\
\text { indicated COVID-19, test and chest } \\
\text { X-ray obtained. Transported on } \\
\text { isolation stretcher to CT unit. }\end{array}$ & $\begin{array}{l}\text { Before isolation strategies } \\
\text { implemented: emergency department } \\
\text { shut down for } 2 \text { hours of cleaning } \\
1.6 \text { times/day; after isolation } \\
\text { strategies } 0.6 \text { times/day. }\end{array}$ \\
\hline
\end{tabular}


Table 8. Cont.

\section{Interventions to Decrease Respiratory Disease Transmission Using Masks, Hand Washing, and Isolation}

\begin{tabular}{lll}
\hline Author, Date & \multicolumn{1}{c}{ Setting } & \multicolumn{1}{c}{ Interventions } \\
\hline & $\begin{array}{l}\text { Model of infection control room } \\
\text { for airborne infectious. Manikin } \\
\text { used to assess flow of potentially } \\
\text { contaminated air from patient in } \\
\text { bed directed to HCW providing } \\
\text { care }\end{array}$ & $\begin{array}{l}\text { Fresh external air flowed over } \\
\text { patient's bed from ceiling vent and } \\
\text { vented externally: venting either } \\
\text { ceiling vent, single vent under bed, } \\
\text { or two vents 1.2m above floor } \\
\text { behind patient's bed. Air flows } \\
\text { visualised by fog generator from } \\
\end{array}$ \\
& & $\begin{array}{l}\text { manikin's mouth using SF } \text { (sodium }_{6} \\
\text { hexafluoride). }\end{array}$
\end{tabular}

Outcomes or Observations

For HCW $1.4 \mathrm{~m}$ from patient concentration of $\mathrm{SF}_{6}$ with ceiling exhaust 33.1 to $72.7 \mathrm{ppm}$, with exhaust under bed 25.1 to $34.4 \mathrm{ppm}$, with dual exhausts in wall behind the bed 21.2 to 24.4 ppm and for two exhausts in the wall either side of bed with a Fan Filter Unit (FFU) with a 0.3-micron pore size HEPA filter (rated 99.997\% efficient at retaining particles) concentration $1.4 \mathrm{~m}$ and $0.9 \mathrm{~m}$ above the floor was 2.0 to 8.9 ppm, $85.2 \%$ lower than without the FFU and for the whole room $79.6 \%$ lower than without the FFU.

\section{Model of model isolation room. Air flowed into the room and was} exhausted by vents at the top of the room. Air flows were filmed and change in air flows visualised with smoke generator as door opened, manikin entered and doors closed.

Kalliomäki 2016 [83]

\section{During 24 second period as doors} opened and manikin entered room the plume of smoke was dragged by the manikin into the room, the plume passed in front of manikin and mixed with the room air and doors closed. More air influx occurred with hinged doors than sliding doors.

Model clean room with air pressure $15 \mathrm{~Pa}>$ anteroom and anteroom $10 \mathrm{~Pa}>$ surrounding room.
Manikin walking speed $0 \mathrm{~m} / \mathrm{s}$, $0.5 \mathrm{~m} / \mathrm{s}, 1.0 \mathrm{~m} / \mathrm{s}$ (=fast walking; airflow rates in cleanroom $200 \mathrm{~L} / \mathrm{s}$, $400 \mathrm{~L} / \mathrm{s}, 580 \mathrm{~L} / \mathrm{s}$; TSI Atomizer 9302 particle generator generated particles 0.5 to $3.0 \mu \mathrm{m}$ with $25 \mathrm{psi}$ pressure.

Particle concentration in clean room before door opening range 18,519 to $100,482 / \mathrm{m}^{3}$ (meets ISO 14644

specification for classes 6 and 7) With door closed no particles entered cleanroom due to overpressure of $15 \mathrm{~Pa}$; few particles entered with door opening and closing. When manikin entered walking at $0.5 \mathrm{~m} / \mathrm{s}$ and airflow rate $210 \mathrm{~L} / \mathrm{s} 840,994$ particles $/ \mathrm{m}^{3}$ entered cleanroom; at $400 \mathrm{~L} / \mathrm{s} 83,774$ particles $/ \mathrm{m}^{3}$ and at $580 \mathrm{~L} / \mathrm{s} 42,407$ particles $/ \mathrm{m}^{3}$ (meets ISO 14644 Class 7 specification); Particle counts in cleanroom tripled with manikin entering at fast walking speed of $1 \mathrm{~m} / \mathrm{s}: 1,745,142 / \mathrm{m}^{3}$ at $210 \mathrm{~L} / \mathrm{s} ; 247,580 / \mathrm{m}^{3}$ at $440 \mathrm{~L} / \mathrm{s}$ and $120,417 / \mathrm{m}^{3}$ at $580 \mathrm{~L} / \mathrm{s}$.

Model conversion of patient room to an isolation room with a temporary anteroom and air purifier.
Two High Efficiency Particulate Air (HEPA) machines drew air from patient room at $1500 \mathrm{~m}^{3} \mathrm{~h}^{-1}$ to exterior yielding 20 air changes/hour and a negative pressure of 2.5 Pa. Particle concentration in patient room < 1000 for particle size $0.3 \mu \mathrm{m}$ Nebuliser released aerosols at $10^{5}$ particles/L from manikin's head lying in bed (1000 above room concentration to simulate a

SARS-CoV-2 virus count from a cough).
Marked increase in concentration within patient room with aerosol simulating coughing. Highest migration rate from patient room for particles $<3 \mu \mathrm{m}$ compared to $>3 \mu \mathrm{m}$. Plastic barrier in anteroom without HEPA filters prevented spread of $80 \%$ of particles.

HEPA filters markedly reduced particle counts in anteroom and hallway.
Mousavi 2020 [85]

A study in an emergency department demonstrated a reduction in cleaning needs after contamination by potential SARS-CoV-2 patients [81]. Four modelling studies demonstrated how to minimise the contamination of airflows in respiratory disease isolation rooms. One found that directing fresh airflows from the ceiling over the patient's bed and exhausting airflows through the wall behind the bed caused the least contamination of a manikin representing an HCW standing in front of the patient to provide care [82]. A study 
of contamination from door opening as a manikin representing an HCW entered from an anteroom found sliding doors reduced contamination compared to opening doors [83]. A study of pharmaceutical cleanrooms found that with the door from the anteroom closed, no particles entered the cleanroom due to the overpressure of $15 \mathrm{~Pa}$ and few particles entered with door opening and closing. When an individual entered the cleanroom walking fast at $1 \mathrm{~m} / \mathrm{s}$ with low air flows $(210 \mathrm{~L} / \mathrm{s})$, contamination was tripled compared to a lower speed of $0.5 \mathrm{~m} / \mathrm{s}$ and a high air flow of $580 \mathrm{~L} / \mathrm{second}$ [84]. Another study using a particle generator showed a marked increase in particle concentration within a patient room with the aerosol simulating coughing. The highest particle migration rate from the patient room to the anteroom was for particles $<3 \mu \mathrm{m}$ (simulating SARS-CoV-2) compared to $>3 \mu \mathrm{m}$. A plastic barrier in the anteroom even without HEPA filters prevented the spread of $80 \%$ of particles and HEPA filters markedly reduced particle counts in the anteroom and hallway [85].

Several studies have demonstrated how large rooms or a group of rooms in a medical facility can rapidly be converted into isolation facilities by changing air flows [86-91]. In a skilled nursing facility in Lancaster, Pennsylvania, USA, an existing HVAC system was modified to minimise disease transmission between residents and staff and maintained an average pressure differential of $-2.3 \mathrm{~Pa}(\mathrm{SD}=0.12 \mathrm{~Pa})$ with the external hallway, and no transmission of SARS-CoV-2 between residents isolated to the space or transmission to the staff or other residents occurred [92].

There is very limited information on the contamination of surfaces and food in LTCFs [93-95]. A systematic review estimated that COVID-19 is not detectable on steel or plastic after seven days, glass after four days and wood after one day [96]. Another systematic review of 26 studies up to 4 February 2021 of the contamination of surfaces by SARS-CoV-2 RNA in hospitals analysed 3101 samples acquired before disinfection. For the nine studies with 100 or more samples, the rate ranged from $1.4 \%$ to $19 \%$. No summary was provided for all 26 studies, but summarising the authors' Table 1, there were nine studies with RNA samples on $0-5 \%$ of the tested surfaces, six studies with $6-10 \%$, seven studies with $11-20 \%$, five studies with $21-40 \%$, three studies with $41-60 \%$ and four studies with $61-100 \%$ [97]. A c-RCT used UVC lamps in rooms previously occupied by patients with methicillin-resistant staphylococcus aureus, vancomycin-resistant enterococcus, C. difficile, or multidrug-resistant Acinetobacter. Rooms cleaned with quaternary ammonium cleaners (QUAD) had 51.3 cases of the targeted organisms /10,000 patient days, and for UV added to QUAD the incidence in exposed patients was 33.9 cases /10,000 exposure days, (relative risk (RR) $0.70,95 \%$ CI $0.50-0.98 ; p=0.036$ ) $[98,99]$. A non-randomised study found a $90 \%$ reduction in viral counts within six minutes and $99.5 \%$ in 11 minutes [100]. The effects of UV-C need more modeling particularly with attention to the effectiveness of decolonisation with distance from objects [101].There is evidence that copper surfaces reduce SARS-CoV-2 contamination levels [102-107].

An important issue is identifying risks to LTCFs from being situated in communities with higher SARS-CoV-2 rates to which potential new residents, visitors and HCWs are exposed. A study used the US Centers for Medicare and Medicaid Services database of 14,886 nursing homes to identify nursing homes at risk of higher rates of COVID-19 and thus needing prioritising to promptly implement comprehensive COVID-19 prevention interventions. The nursing homes at risk had more residents; had received more Medicaid penalties, health deficiencies and deficiencies related to infections; had lower total staff and aide numbers; and were located in counties with higher COVID-19 rates, higher density communities, more residents in nursing homes, minorities, unemployed individuals and persons living below the poverty line (all $p<0.001)$. Health departments need to prioritise such homes for interventions to minimise respiratory disease outbreaks and disease rates [108]. 
Table 9. UVC lights to decrease surface and air contamination in nursing homes.

\begin{tabular}{|c|c|c|c|}
\hline Author, Date & Setting & Interventions & Outcomes or Observations \\
\hline Anderson 2017 [98], 2018 [99] & $\begin{array}{l}\text { C-RCT, } 9 \text { hospitals, SE USA, } \\
\text { single rooms from which patients } \\
\text { had been discharged who had had } \\
\text { positive cultures of four target } \\
\text { organisms in previous } 12 \text { months. }\end{array}$ & $\begin{array}{l}\text { 21,395 patients randomised to } 4 \\
\text { study arms: (1) quaternary } \\
\text { ammonium disinfectant (QUAD) } \\
\text { (except bleach for C. difficile); (2) } \\
\text { UV and QUAD (or UV and bleach } \\
\text { for C. difficile); (3) bleach; (4) } \\
\text { bleach and UV. Randomisation by } \\
\text { random-number generator, } 99 \% \\
\text { power to detect } 20 \% \text { decrease in } \\
\text { incidence rates, microbiological } \\
\text { identification used standard } \\
\text { protocols, environmental services } \\
\text { personnel trained on use of } \\
\text { disinfectants, cleaning protocols, } \\
\text { UV lights; compliance with } \\
\text { protocols, hand hygiene and } \\
\text { cleaning similar across study } \\
\text { groups, cleaning compliance } 90 \% \text {; } \\
\text { QUAD applied using microfibre } \\
\text { cloths (which remove more } \\
\text { bacteria than cotton or synthetic } \\
\text { fibres). }\end{array}$ & 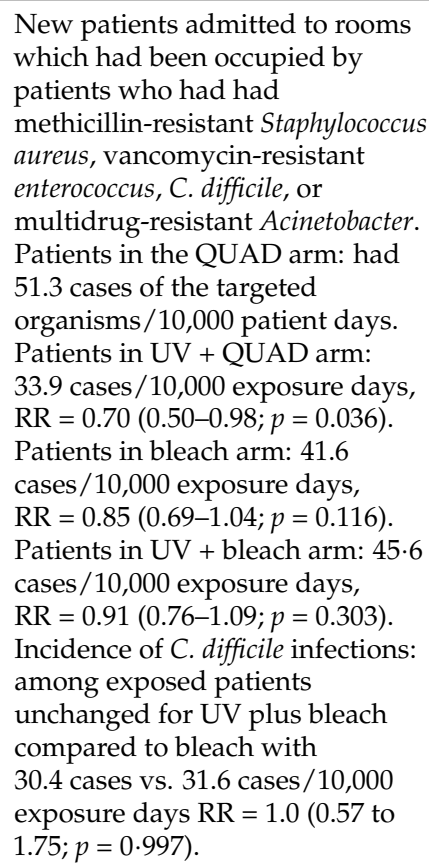 \\
\hline Ethington 2018 [97] & $\begin{array}{l}\text { Before-after study of special care } \\
\text { unit of a long-term acute care } \\
\text { hospital. }\end{array}$ & $\begin{array}{l}\text { Airborne bacterial colony forming } \\
\text { units (CFU) } / \mathrm{m}^{3} \text { of air were } \\
\text { measured in } 16 \text { patient rooms, } \\
\text { hallway and biohazard room. } \\
\text { Ultra-violet germicidal irradiation } \\
\text { equipment installed in these } \\
\text { locations. }\end{array}$ & $\begin{array}{l}\text { On resampling } 81 \text { days later } 42 \% \\
\text { decline in number of airborne } \\
\text { bacteria } \mathrm{CFU} / \mathrm{m}^{3} \text { (average } 175 \mathrm{vs} \text {. } \\
\left.102 \mathrm{CFU} / \mathrm{m}^{3}\right) \text {, rate of } \\
\text { infections } / \mathrm{month} \text { in the home } \\
\text { declined from } 20.3 \text { to } 8.6 \\
\text { ( } p=0.001) \text {, annual number of } \\
\text { Clostridium difficile cases declined } \\
\text { from } 8 \text { to } 1 \text { ( } p=0.01 \text { ), annual } \\
\text { number of cases of } \\
\text { catheter-associated urinary } \\
\text { infections declined from } 20 \text { to } 9 \\
\text { ( } p=0.012) \text {. No significant } \\
\text { decreases in cases of } \\
\text { methicillin-resistant } \\
\text { Staphylococcus aureus (13 vs. 6) or } \\
\text { central line-associated } \\
\text { bloodstream infections (16 vs. 9). }\end{array}$ \\
\hline Buchan 2020 [101] & $\begin{array}{l}\text { Model of } 3 \text { meter }^{3} \text { room with air } \\
\text { entry top left, air exit top right } \\
\text { standard ventilation compared to } \\
\text { ultra-violet. }\end{array}$ & $\begin{array}{l}\text { Far-UVC light from excimer } \\
\text { lamps or light-emitting diodes is } \\
\text { safe to use with humans because } \\
\text { it generates narrow bandwidth } \\
\text { short wavelength UVC ( } 207-222 \\
\text { nm) which does not affect cornea. }\end{array}$ & $\begin{array}{l}\text { Far-UVC: Disinfection rates } \\
\text { increased by } 50-85 \% \text {. } \\
\text { Far-UVC and high ventilation ( } 8 \\
\text { air changes/hour): time to } \\
\text { achieve } 90 \% \text { reduction in viral } \\
\text { count }=6 \text { minutes; } 8 \text { air } \\
\text { changes } / \text { hour results in } 99 \% \\
\text { reduction in } 11.5 \text { minutes. }\end{array}$ \\
\hline
\end{tabular}

In the Netherlands, sewage outflows from communities were sampled and COVID-19 was demonstrated in some communities days before COVID-19 was detected in any individual. The Dutch National Institute for Public Health and the Environment (RIVM) samples 318 waste-water treatment plants weekly for coronaviruses. However, there are wide variations in counts between plants depending on how many individuals use a sewage system, and dilution by rain and by industrial water. If PCR tests on humans are performed daily and on sewage weekly, the sewage tests may provide confirmation rather than early detection. Currently, the sewage tests are performed daily and are sent to a central laboratory [109]. 


\section{Discussion}

Worldwide air travel and tourism will increase the extent and rapidity of the spread of respiratory infections and their variants. Viruses and bacteria are widely spread in multiple non-human hosts, and many birds are infected with viruses and distribute them in annual migrations involving many thousands of miles. Many birds and animals are kept in very close proximity in live markets in some countries. More pandemics and more frequent global pandemics are likely.

Seniors and especially seniors with multi-morbidities have incurred more than $80 \%$ of the mortality in the current SARS-CoV-2 pandemic. Sars variants are emerging in Brazil, South Africa and the UK, are more infectious, also affect younger populations more, and constitute a larger proportion of all Sars cases. Many countries are highly motivated with the COVAX strategy to vaccinate their entire populations, but there are groups who do not plan to be vaccinated and a major effort to dialogue with them and understand their reasons is essential. Vaccination rates for pneumococcal disease and influenza are suboptimal in most countries. Large RCTs are needed with health workers to assess the effects on the patients they care for of optimal hand washing, social distancing, vaccination and PPE in countries where they are provided.

Comprehensive preventive interventions need to be implemented in nursing homes and LTCFs as described in the text, with rigorous monitoring with the CDC COVID tools for the comprehensive implementation of preventive interventions. Patients need to be provided with single rooms with their own air system, and hospitals structured to vent potentially infected air from each patient room, hallway and common room externally with microbiological sampling of the air and high touch surfaces. Automatic monitoring for the current vaccination status of residents, HCWs and visitors should be implemented by linking to national vaccination registers. Regular testing of patients and $\mathrm{HCWs}$, high rates of vaccination, handwashing and PPE (gloving, mask wearing, eye protection and gown wearing, if these are provided) should be encouraged because current studies demonstrate that these interventions are often inadequately used and increased vaccination results in lower transmission rates.

\section{Conclusions}

Individuals $\geq 65$ have high rates of morbidity and mortality due to COVID-19 infections and those in nursing homes and LTCFs are frail, have multiple co-morbidities and are especially vulnerable. Interventions are needed to reduce these rates.

\subsection{Detection}

Rapid detection of the first case of COVID-19 or other respiratory pathogens in a community and in nursing homes and LTCFs is very important in instituting a prompt comprehensive infection control plan with daily monitoring of staff and residents for symptoms, testing of patients and staff on a regular schedule, and contact tracing. As at the beginning of an outbreak there may be no symptomatic individuals in a community, an environmental approach to detect early clues of COVID-19 in a community may give useful warning by testing sewage for viruses.

\subsection{Identification of Nursing Homes Most in Need of Help Implementing Comprehensive Infection} Control Plans

Nursing homes vary greatly in the level of care they provide and this is likely to be reflected in their infection and mortality rates. The COVID-19 CDC tool is a comprehensive list of quality of care indicators which identifies nursing homes in a region most in need of help to control infections [61].

\subsection{Implementation of Comprehensive Infection Control Plans}

Comprehensive plans involve closing the home to new admissions from potentially infected individuals, contact and droplet precautions for all confirmed, suspected or 
exposed COVID-19 cases, quarantining patients with symptoms in isolation wards until they can be tested as positive or cleared, universal personal protective equipment (PPE) for all staff, visitors, all residents and individuals entering any unit screened daily for temperature and symptoms, admitting visitors who have been vaccinated and according to current local regulations, and cohorting staff to provide care only on specific units. The plans need to be implemented by dedicated teams of infection control specialists for the entire group of nursing homes in a community and the rapidity and completeness of implementation need to be closely monitored.

\subsection{Restructuring Nursing Homes to Reduce Crowding}

Higher crowding indices (four patients/room compared to single rooms) correlate with higher infection rates. The structural conditions should be adapted in order to be able to react more quickly to new outbreaks and new pandemic situations, e.g., due to new variants of SARS-CoV-2 or other rapidly transmissible pathogens. Ideally, each patient should have their own bathroom and toilet and an anteroom at the entrance to their room for washing and personal protective equipment so that staff and visitors can prevent the transmission of infection.

\subsection{Upgrading Ventilation Systems in Nursing Homes}

All patient rooms, hallways and common rooms need to have their own fresh air supply from an external source without recirculation and exhaust to the outside, with fresh air entering over the patient's bed and exhausting behind the bed to avoid flowing over HCWs standing in front of them providing care. Infected or potentially infected patients need to be transported on isolation stretchers with their own air supply.

\subsection{Increasing Influenza, Pneumococcal and SARS-CoV-2 Vaccination Rates in Seniors}

Vaccination rates for influenza and pneumococcal disease are inadequate, especially in older seniors. Worldwide, there are vaccination plans for the comprehensive vaccination of seniors against coronaviruses, but there are individuals who are hesitant to be vaccinated. There are limited data on the effectiveness of these vaccinations in older people and additional efforts to protect them from potential infection are needed.

\subsection{Identifying Interventions Programmed to Function Automatically}

The intervention least dependent on the training, motivation and close supervision of patients and staff is to upgrade the ventilation systems in nursing homes so that each patient has an individual room and that all patient rooms, hallways and common rooms receive fresh air from the outside and vent the air to the outside. Due to ethical issues in exposing volunteer subjects to infections, research has involved models of hospital rooms with manikins and visualised air flows. A c-RCT implementing individual ventilation with external air entry and venting for each patient room, common room and hallway in LTCFs and microbiological sampling is needed.

Automatic monitoring of the current vaccination status of patients, staff and visitors by linking to national vaccination registries would be very helpful. Training and monitoring of standard infection reduction strategies with personal protective equipment (handwashing, mask wearing, gloving and eye protection) and especially of the WHO's five steps in the prevention of transmission of infections would be most useful. Daily monitoring of infectious disease infection rates in communities and the LTCFs within them to trigger comprehensive infection control policies is also an important intervention. Clear public health and political responsibility for closely monitoring and assisting implementation is necessary.

Funding: This research received no external funding.

Institutional Review Board Statement: Not applicable.

Informed Consent Statement: Not applicable. 


\section{Data Availability Statement: Not applicable.}

Conflicts of Interest: The author declares no conflict of interest.

\section{References}

1. Crowe, J.E., Jr. Common Viral Respiratory Infections. In Harrison's Principles of Internal Medicine, 20th ed.; Jameson, J.L., Fauci, A.S., Kasper, D.L., Hauser, S.L., Longo, D.L., Loscalzo, J., Eds.; McGraw-Hill Education: New York, NY, USA, 2018.

2. Centers for Disease Control and Prevention. Older Adults at Greater Risk of Requiring Hospitalization or Dying If Diagnosed with COVID-19. Available online: https://www.cdc.gov/coronavirus/2019-ncov/need-extra-precautions/older-adults.html (accessed on 12 February 2021).

3. Yanez, N.D.; Weiss, N.S.; Romand, J.A.; Treggiari, M.M. COVID-19 mortality risk for older men and women. BMC Public Health 2020, 20, 1742. [CrossRef]

4. Vossius, C.; Selbæk, G.; Benth, J. Šaltytė; Bergh, S. Mortality in nursing home residents: A longitudinal study over three years. PLOS ONE 2018, 13, e0203480. [CrossRef]

5. McCann, M.; O’Reilly, D.; Cardwell, C. A Census-based longitudinal study of variations in survival amongst residents of nursing and residential homes in Northern Ireland. Age Ageing 2009, 38, 711-717. [CrossRef]

6. Wieland, D.; Boland, R.; Baskins, J.; Kinosian, B. Five-Year Survival in a Program of All-Inclusive Care for Elderly Compared with Alternative Institutional and Home-and Community-Based Care. J. Gerontol. A Biol. Sci. Med. Sci. 2010, 65, 721-726. [CrossRef]

7. Hjaltadottir, I.; Hallberg, I.R.; Ekwall, A.K.; Nyberg, P. Predicting mortality of residents at admission to nursing home: A longitudinal cohort study. BMC Health Serv. Res. 2011, 19, 1-86. [CrossRef]

8. Li, S.; Middleton, A.; Ottenbacher, K.J.; Goodwin, J.S. Trajectories Over the First Year of Long-Term Care Nursing Home Residence. J. Am. Med Dir. Assoc. 2018, 19, 333-341. [CrossRef]

9. Gambassi, G.; Landi, F.; Lapane, K.L.; Sgadari, A.; Mor, V.; Bernabei, R. Predictors of mortality in patients with Alzheimer's disease living in nursing homes. J. Neurol. Neurosurg. Psychiatry 1999, 67, 59-65. [CrossRef]

10. Vossius, C.; Nilsen, O.B.; Larsen, J.P. Parkinson's disease and nursing home placement: The economic impact of the need for care. Eur. J. Neurol. 2009, 16, 194-200. [CrossRef] [PubMed]

11. Tabue-Teguo, M.; Kelaiditi, E.; Demougeot, L.; Dartigues, J.F.; Vellas, B.; Cesari, M. Frailty Index and Mortality in Nursing Home Residents in France: Results from the INCUR Study. J. Am. Med Dir. Assoc. 2015, 16, 603-606. [CrossRef] [PubMed]

12. Dwyer, R.; Gabbe, B.; Stoelwinder, J.U.; Lowthian, J. A systematic review of outcomes following emergency transfer to hospital for residents of aged care facilities. Age Ageing 2014, 43, 759-766. [CrossRef] [PubMed]

13. Canadian Institute of Health Information. Profile of Residents in Residential and Hospital-Based Continuing Care, 2019-2020. 2020. Available online: ccrs-qick-stats-2019-2020-en-xlsx (accessed on 10 January 2021).

14. Harris-Kojetin, L.; Sengupta, M.; Lendon, J.P.; Rome, V.; Valverde, R.; Caffrey, C. Long-Term Care Providers and Services Users in the United States, 2015-2016. Vital Health Stat. 2019, 38, 1-105.

15. Lee, M.H.; Lee, G.A.; Lee, S.H.; Park, Y.H. A systematic review on the causes of the transmission and control measures of outbreaks in long-term care facilities: Back to basics of infection control. PLoS ONE 2020, 15, e0229911. [CrossRef] [PubMed]

16. Kim, S.Y.; Park, J.E.; Lee, Y.J.; Seo, H.J.; Sheen, S.S.; Hahn, S.; Jang, B.H.; Son, H.J. Testing a tool for assessing the risk of bias for nonrandomized studies showed moderate reliability and promising validity. J. Clin. Epidemiol. 2013, 66, 408-414. [CrossRef] [PubMed]

17. Childs, A.; Zullo, A.R.; Joyce, N.R.; McConeghy, K.W.; van Aalst, R.; Moyo, P.; Bosco, E.; Mor, V.; Gravenstein, S. The burden of respiratory infections among older adults in long-term care: A systematic review. BMC Geriatr. 2019, 19, 210. [CrossRef]

18. Shen, A.K.; Warnock, R.; Selna, W.; MaCurdy, T.E.; Chu, S.; Kelman, J.A. Vaccination among Medicare-fee-for service beneficiaries: Characteristics and predictors of vaccine receipt, 2014-2017. Vaccine 2019, 37, 1194-1201. [CrossRef]

19. Public Health Agency of Canada. Seasonal Influenza Vaccination Coverage in Canada, 2019-2020. Available online: https:/ / www.canada.ca/en/public-health/services/immunization-vaccines/vaccination-coverage/2019-2020-seasonalinfluenza-flu-vaccine-coverage.html\#vaccination_coverage (accessed on 24 January 2021).

20. Ramos, J.M.; García-Navarro, M.M.; González de la Aleja, M.P.; Sánchez-Martínez, R.; Gimeno-Gascón, A.; Reus, S.; Merino, E.; Rodríguez-Díaz, J.C.; Portilla, J. Seasonal influenza in octogenarians and nonagenarians admitted to a general hospital: Epidemiology, clinical presentation and prognostic factors. Rev. Esp. Quimioter. 2016, 29, 296-301. [PubMed]

21. Shi, S.M.; Bakaev, I.; Chen, H.; Travison, T.G.; Berry, S.D. Risk Factors, Presentation, and Course of Coronavirus Disease 2019 in a Large, Academic Long-Term Care Facility. J. Am. Med. Dir. Assoc. 2020, 21, 1378-1383.e1. [CrossRef]

22. McMichael, T.M.; Currie, D.W.; Clark, S.; Pogosjans, S.; Kay, M.; Schwartz, N.G.; Lewis, J.; Baer, A.; Kawakami, V.; Lukoff, M.D.; et al. Epidemiology of Covid-19 in a Long-Term Care Facility in King County, Washington. N. Engl. J. Med. 2020, 382, $2005-2011$. [CrossRef]

23. Kennelly, S.P.; Dyer, A.H.; Noonan, C.; Martin, R.; Kennelly, S.M.; Martin, A.; O’Neill, D.; Fallon, A. Asymptomatic carriage rates and case fatality of SARS-CoV-2 infection in residents and staff in Irish nursing homes. Age Ageing 2021, 50, 49-54. [CrossRef]

24. World Health Organization. WHO R\&D Blueprint: Novel Coronavirus COVID-19 Therapeutic Trial Synopsis. 2020. Available online: https://apps.who.int/iris/bitstream/handle/10665/330694/WHO-HEO-RDBlueprintnCoV-2020.4-eng.pdf?sequence= 1\&isAllowed=y (accessed on 12 February 2021). 
25. Garibaldi, B.T.; Fiksel, J.; Muschelli, J.; Robinson, M.L.; Rouhizadeh, M.; Perin, J.; Schumock, G.; Nagy, P.; Gray, J.H.; Malapati, H.; et al. Patient Trajectories Among Persons Hospitalized for COVID-19: A Cohort Study. Ann. Intern. Med. 2021, 174, 33-41. [CrossRef]

26. Telle, K.E.; Grøsland, M.; Helgeland, J.; Håberg, S.E. Factors associated with hospitalization, invasive mechanical ventilation treatment and death among all confirmed COVID-19 cases in Norway: Prospective cohort study. Scand. J. Public Health 2021, 49, 41-47. [CrossRef]

27. Tarteret, P.; Strazzulla, A.; Rouyer, M.; Gore, C.; Bardin, G.; Noel, C.; Benguerdi, Z.E.; Berthaud, J.; Hommel, M.; Aufaure, S.; et al. Clinical features and medical care factors associated with mortality in French nursing homes during the COVID-19 outbreak. Int. J. Infect. Dis. 2021, 104, 125-131. [CrossRef] [PubMed]

28. Gopal, R.; Han, X.; Yaraghi, N. Compress the curve: A cross-sectional study of variations in COVID-19 infections across California nursing homes. BMJ Open 2021, 11, e042804. [CrossRef]

29. Castriotta, L.; Rosolen, V.; Barbiero, F.; Tomietto, M.; De Dottori, M.; Barbone, F.; Zamaro, G. Impact of the COVID-19 epidemic in Friuli Venezia Giulia Region (Northern Italy): Assessment of factors associated with the risk of death by competing risks analysis. Epidemiol. Prev. 2021, 44, 128-135.

30. US Centers for Medicare and Medicaid Services. Quality ID \#111: Pneumococcal Vaccination Status for Older Adults. Available online: https://qpp.cms.gov/docs/QPP_quality_measure_specifications/Claims-Registry-Measures/2020_Measure_11 1_MedicarePartBClaims.pdf (accessed on 27 December 2020).

31. Chalmers, J.D.; Campling, J.; Dicker, A.; Woodhead, M.; Madhava, H. A systematic review of the burden of vaccine pre-ventable pneumococcal disease in UK adults. BMC Pulm. Med. 2016, 16, 1-11. [CrossRef]

32. Van Hoek, A.J.; Andrews, N.; Waight, P.A.; George, R.; Miller, E. Effect of serotype on focus and mortality of invasive pneumococcal disease: Coverage of different vaccines and insight into non-vaccine serotypes. PLoS ONE 2012, 7, e39150. [CrossRef]

33. Waight, P.A.; Andrews, N.J.; Ladhani, S.N.; Sheppard, C.L.; Slack, M.P.; Miller, E. Effect of the 13-valent pneumococcal conjugate vaccine on invasive pneumococcal disease in England and Wales 4 years after its introduction: An observational cohort study. Lancet Infect. Dis. 2015, 15, 535-543. [CrossRef]

34. Norris, T.; Vahratian, A.; Cohen, R.A.; US Centers for Disease Control. Vaccination Coverage among Adults Aged 65 and Over: United States. 2015. Available online: www.cdc.gov/nchs/data/databriefs/db281.pdf (accessed on 27 December 2020).

35. Black, C.L.; Williams, W.W.; Arbeloa, I.; Kordic, N.; Yang, L.; MaCurdy, T.; Worrall, C.; Kelman, J.A. Trends in Influenza and Pneumococcal Vaccination Among US Nursing Home Residents, 2006-2014. J. Am. Med. Dir. Assoc. 2017, 18, 735. [CrossRef]

36. Vila-Córcoles, A.; Ochoa-Gondar, O.; De Diego, C.; Satué, E.; Vila-Rovira, A.; Aragón, M. Pneumococcal vaccination coverages by age, sex and specific underlying risk conditions among middle-aged and older adults in Catalonia, Spain, 2017. Eurosurveillance 2019, 24, 24. [CrossRef]

37. Wang, Y.; Cheng, M.; Wang, S.; Wu, F.; Yan, Q.; Yang, Q.; Li, Y.; Guo, X.; Fu, C.; Shi, Y.; et al. Vaccination coverage with the pneumococcal and influenza vaccine among persons with chronic diseases in Shanghai, China, 2017. BMC Public Health 2020, 20, 1-9. [CrossRef]

38. Djennad, A.; Ramsay, M.E.; Pebody, R.; Fry, N.K.; Sheppard, C.; Ladhani, S.N.; Andrews, N.J. Effectiveness of 23-Valent Polysaccharide Pneumococcal Vaccine and Changes in Invasive Pneumococcal Disease Incidence from 2000 to 2017 in Those Aged 65 and Over in England and Wales. E Clin. Med. 2018, 6, 42-50. [CrossRef]

39. Thomas, R.E.; Lorenzetti, D.L. Interventions to increase influenza vaccination rates of those 60 years and older in the community. Cochrane Database Syst. Rev. 2018, 5, CD005188. [CrossRef] [PubMed]

40. Gravenstein, S.; Davidson, H.E.; Taljaard, M.; Ogarek, J.; Gozalo, P.; Han, L.; Mor, V. Comparative effectiveness of high-dose versus standard-dose influenza vaccination on numbers of US nursing home residents admitted to hospital: A cluster-randomised trial. Lancet Respir. Med. 2017, 5, 738-746. [CrossRef]

41. Naito, T.; Suzuki, M.; Fujibayashi, K.; Kanazawa, A.; Takahashi, H.; Yokokawa, H.; Watanabe, A. The estimated impact of the 5 -year national vaccination program on the trend of 23-valent pneumococcal polysaccharide vaccine vaccination rates in the elderly in Japan, 2009-2018. J. Infect. Chemother. 2020, 26, 407-410. [CrossRef]

42. Murakami, Y.; Kanazu, S.; Petigara, T.; Oba, M.S.; Nishiwaki, Y.; Watanabe, A. Factors associated with PPSV23 coverage among older adults in Japan: A nationwide community-based survey. BMJ Open 2019, 9, e030197. [CrossRef]

43. Public Health England. Pneumococcal Polysaccharide Vaccine (ppv) Coverage Report, England, April 2017 to March 2018. Health Protection Report. Available online: https://www.gov.uk/government/publications/pneumococcalpolysaccharide-vaccineppvvaccine-coverage-estimates (accessed on 20 December 2020).

44. Dyda, A.; Karki, S.; Hayen, A.; MacIntyre, C.R.; Menzies, R.; Banks, E.; Kaldor, J.M.; Liu, B. Influenza and pneumococcal vaccination in Australian adults: A systematic review of coverage and factors associated with uptake. BMC Infect. Dis. 2016, 16, 1-15. [CrossRef]

45. Yang, T.U.; Kim, E.; Park, Y.-J.; Kim, D.; Kwon, Y.H.; Shin, J.K.; Park, O. Successful introduction of an underutilized elderly pneumococcal vaccine in a national immunization program by integrating the pre-existing public health infrastructure. Vaccine 2016, 34, 1623-1629. [CrossRef]

46. Thomas, R.E.; Jefferson, T.; Lasserson, T.J. Influenza vaccination for healthcare workers who care for people aged 60 or older living in long-term care institutions. Cochrane Database Syst. Rev. 2013, 7. [CrossRef] 
47. Thomas, R.E.; Jefferson, T.; Lasserson, T.J. Influenza vaccination for healthcare workers who care for people aged 60 or older living in long-term care institutions. Cochrane Database Syst. Rev. 2016, 6. [CrossRef] [PubMed]

48. Potter, J.; Stott, D.J.; Roberts, M.A.; Elder, A.G.; O’Donnell, B.; Knight, P.V.; Carman, W.F. Influenza Vaccination of Health Care Workers in Long-Term-Care Hospitals Reduces the Mortality of Elderly Patients. J. Infect. Dis. 1997, 175, 1-6. [CrossRef] [PubMed]

49. Carman, W.F.; Elder, A.G.; Wallace, L.A.; McAulay, K.; Walker, A.; Murray, G.D.; Stott, D.J. Effects of influenza vaccination of health-care workers on mortality of elderly people in long-term care: A randomized controlled trial. Lancet 2000, 355, 93-97. [CrossRef]

50. Hayward, A.C.; Harling, R.; Wetten, S.; Johnson, A.M.; Munro, S.; Smedley, J.; Murad, S.; Watson, J.M. Effectiveness of an influenza vaccine programme for care home staff to prevent death, morbidity, and health service use among residents: Cluster randomised controlled trial. BMJ 2006, 333, 1241. [CrossRef] [PubMed]

51. Lemaitre, M.; Meret, T.; Rothan-Tondeur, M.; Belmin, J.; Lejonc, J.L.; Luquel, L.; Piette, F.; Salom, M.; Verny, M.; Vetel, J.M.; et al. Effect of Influenza Vaccination of Nursing Home Staff on Mortality of Residents: A Cluster-Randomized Trial. J. Am. Geriatr. Soc. 2009, 57, 1580-1586. [CrossRef]

52. Thomas, R.E. Is influenza-like illness a useful concept and an appropriate test of influenza vaccine effectiveness? Vaccine 2014, 32, 2143-2149. [CrossRef]

53. Thomas, R.E. Do we have enough evidence how seasonal influenza is transmitted and can be prevented in hospitals to implement a comprehensive policy? Vaccine 2016, 34, 3014-3021. [CrossRef] [PubMed]

54. Lytras, T.; Kopsachilis, F.; Mouratidou, E.; Papamichail, D.; Bonovas, S. Interventions to increase seasonal influenza vaccine coverage in healthcare workers: A systematic review and meta-regression analysis. Hum. Vaccin Immunother. 2016, 12, 671-681. [CrossRef]

55. De Serres, G.; Skowronski, D.M.; Ward, B.J.; Gardam, M.; Lemieux, C.; Yassi, A.; Patrick, D.M.; Krajden, M.; Loeb, M.; Collignon, P.; et al. Influenza Vaccination of Healthcare Workers: Critical Analysis of the Evidence for Patient Benefit Underpinning Policies of Enforcement. PLoS ONE 2017, 12, e0163586. [CrossRef]

56. World Health Organization Regional Office for Europe. Prevention and Control of Outbreaks of Seasonal Influenza in Long-term Care Facilities: A Review of the Evidence and Best Practice Guidance. 2017. Available online: http://www.euro.who.int/_data/ assets / pdf_file/0015/330225/LTCF-best-practice-guidance.pdf?ua=1 (accessed on 24 January 2021).

57. Lansbury, L.E.; Brown, C.S.; Nguyen-Van-Tam, J.S. Influenza in long-term care facilities. Influ. Other Respir. Viruses 2017, 11, 356-366. [CrossRef]

58. Corace, K.M.; Srigley, J.A.; Hargadon, D.P.; Yu, D.; MacDonald, T.K.; Fabrigar, L.R.; Garber, G.E. Using behavior change frameworks to improve healthcare worker influenza vaccination rates: A systematic review. Vaccine 2016, 34, 3235-3242. [CrossRef]

59. US Centers for Disease Control and Prevention. Testing and Management Considerations for Nursing Home Residents with Acute Respiratory Illness Symptoms When Sars-CoV-2 and Influenza Viruses Are Cocirculating. Available online: https: / / www.cdc.gov / coronavirus / 2019-ncov/hcp/nursing-home-long-term-care.html (accessed on 9 March 2021).

60. US Centers for Disease control and Prevention. Similarities and Differences between Flu and COVID-19. Available online: https: / / www.cdc.gov / flu/symptoms/flu-vs-covid19.htm (accessed on 9 March 2021).

61. World Health Organisation. Considerations for Implementing and Adjusting Public Health and Social Measures in the Context of COVID-19. Interim Guidance. 2020. Available online: WHO-2019-nCov-Adjusting_PH_measures-2020.2-eng (accessed on 9 March 2021).

62. Dugdale, C.M.; Rubins, D.M.; Lee, H.; McCluskey, S.M.; Ryan, E.T.; Kotton, C.N.; Hurtado, R.M.; Ciaranello, A.L.; Barshak, M.B.; McEvoy, D.S.; et al. Coronavirus Disease 2019 (COVID-19) Diagnostic Clinical Decision Support: A Pre-Post Implementation Study of CORAL (COvid Risk cALculator). Clin. Infect. Dis. 2021, ciab111. [CrossRef]

63. Echeverria, P.; Mas Bergas, M.A.; Puig, J.; Isnard, M.; Massot, M.; Vedia, C.; Peiro, R.; Ordorica, Y.; Pablo, S.; Ulldemolins, M.; et al. COVIDApp as an Innovative Strategy for the Man-agement and Follow-Up of COVID-19 Cases in Long-Term Care Facilities in Catalonia: Implementation Study. JMIR Public Health Surveill. 2020, 6, e21163. [CrossRef]

64. Bigelow, B.F.; Tang, O.; Barshick, B.; Peters, M.; Sisson, S.D.; Peairs, K.S.; Katz, M.J. Outcomes of Universal COVID-19 Testing Following Detection of Incident Cases in 11 Long-term Care Facilities. JAMA Intern. Med. 2021, 181, 127. [CrossRef] [PubMed]

65. CDC. Interim Infection Prevention and Control. Recommendations for Healthcare Personnel during the Coronavirus Disease 2019 (COVID-19) Pandemic. 2020. Available online: https://www.cdc.gov/coronavirus/2019-ncov/hcp/infectioncontrolrecommendations.html (accessed on 30 January 2021).

66. CDC. Preparing for COVID-19 in Nursing Homes. 2020. Available online: https://www.cdc.gov/coronavirus/2019-ncov/hcp/ long-term-care.html (accessed on 30 January 2021).

67. Michihiko Goto, M.; Ueckert, N.; Meiches, R.K.; Perencevich, E.I. Successful multimodal measures preventing coronavirus disease 2019 (COVID-19) outbreaks without universal frequent testing within long-term care units in the Midwestern Veterans' Health Care Network. Inf. Control H. Epidemiol. 2021, 1-3. [CrossRef]

68. Vijh, R.; Prairie, J.; Otterstatter, M.C.; Hu, Y.; Hayden, A.S.; Yau, B.; Daly, P.; Lysyshyn, M.; McKee, G.; Harding, J.; et al. Evaluation of a multisectoral intervention to mitigate the risk of severe acute respiratory coronavirus virus 2 (SARS-CoV-2) transmission in long-term care facilities. Infect. Control Hosp. Epidemiol. 2021, 1, 1-8. [CrossRef] [PubMed] 
69. Telford, C.T.; Onwubiko, U.; Holland, D.P.; Turner, K.; Prieto, J.; Smith, S.; Yoon, J.; Brown, W.; Chamberlain, A.; Gandhi, N.; et al. Preventing COVID-19 Outbreaks in Long-Term Care Facilities Through Preemptive Testing of Residents and Staff Members: Fulton County, Georgia, March-May 2020. MMWR. Morb. Mortal. Wkly. Rep. 2020, 69, 1296-1299. [CrossRef] [PubMed]

70. Belmin, J.; Um-Din, N.; Donadio, C.; Magri, M.; Nghiem, Q.D.; Oquendo, B.; Pariel, S.; Lafuente-Lafuente, C. Coronavirus Disease 2019 Outcomes in French Nursing Homes That Implemented Staff Confinement with Residents. JAMA Netw. Open 2020, 3 , e2017533. [CrossRef] [PubMed]

71. Brown, K.A.; Jones, A.; Daneman, N.; Chan, A.K.; Schwartz, K.L.; Garber, G.E.; Costa, A.P.; Stall, N.M. Association Between Nursing Home Crowding and COVID-19 Infection and Mortality in Ontario, Canada. JAMA Intern. Med. 2021, 181, 229-236. [CrossRef] [PubMed]

72. Federgruen, A.; Naha, S. Crowding Effects Dominate Demographic Attributes in COVID-19 Cases. Int. J. Infect. Dis. 2021, 102, 509-516. [CrossRef]

73. Jones, A.; Watts, A.G.; Khan, S.U.; Forsyth, J.; Brown, K.A.; Costa, A.P.; Bogoch, I.I.; Stall, N.M. Impact of a Public Policy Restricting Staff Mobility Between Nursing Homes in Ontario, Canada During the COVID-19 Pandemic. J. Am. Med. Direct Assoc. 2021, 22, 494-497. [CrossRef]

74. Panagiotou, O.A.; Kosar, C.M.; White, E.M.; Bantis, L.E.; Yang, X.; Santostefano, C.M.; Feifer, R.A.; Blackman, C.; Rudolph, J.L.; Gravenstein, S.; et al. Risk Factors Associated With All-Cause 30-Day Mortality in Nursing Home Residents With COVID-19. JAMA Intern. Med. 2021, 181, 439-448. [CrossRef] [PubMed]

75. Jefferson, T.; Del Mar, C.B.; Dooley, L.; Ferroni, E.; Al-Ansary, L.A.; Bawazeer, G.A.; van Driel, M.L.; Jones, M.A.; Thorning, S.; Beller, E.M.; et al. Physical interventions to interrupt or reduce the spread of respiratory viruses. Cochrane Database Sys Rev. 2020, 11, CD006207.

76. McConeghy, K.W.; Baier, R.; McGrath, K.P.; Baer, C.J.; Mor, V. Implementing a Pilot Trial of an Infection Control Program in Nursing Homes: Results of a Matched Cluster Randomized Trial. J. Am. Med. Dir. Assoc. 2017, 18, 707-712. [CrossRef]

77. Temime, L.; Cohen, N.; Ait-Bouziad, K.; Denormandie, P.; Dab, W.; Hocine, M.N. Impact of a multicomponent hand hygienerelated intervention on the infectious risk in nursing homes: A cluster randomized trial. Am. J. Infect. Control 2018, 46, 173-179. [CrossRef]

78. Yeung, W.K.; Tam, W.S.W.; Wong, T.W. Clustered Randomized Controlled Trial of a Hand Hygiene Intervention Involving Pocket-Sized Containers of Alcohol-Based Hand Rub for the Control of Infections in Long-Term Care Facilities. Infect. Control Hosp. Epidemiol. 2011, 32, 67-76. [CrossRef]

79. Cheng, V.C.C.; Chen, H.; Wong, S.C.; Chen, J.H.K.; Ng, W.C.; So, S.Y.C.; Chan, T.C.; Wong, S.C.Y.; Ho, P.L.; Mody, L.; et al. Role of Hand Hygiene Ambassador and Implementation of Directly Observed Hand Hygiene Among Residents in Residential Care Homes for the Elderly in Hong Kong. Infect. Control Hosp. Epidemiol. 2018, 39, 571-577. [CrossRef] [PubMed]

80. Chu, D.K.; Duda, S.; Solo, K.; Yacoub, S.; Schünemann, H.J. Physical distancing, face masks, and eye protection to prevent person-to-person transmission of SARS-CoV-2 and COVID-19: A systematic review and meta-analysis. Lancet 2020, 395, 1973-1987. [CrossRef]

81. Kim, S.C.; Kong, S.Y.; Park, G.J.; Lee, J.H.; Lee, J.K.; Lee, M.S.; Han, H.S. Effectiveness of negative pressure isolation stretcher and rooms for SARS-CoV-2 nosocomial infection control and maintenance of South Korean emergency department capacity. Am. J. Emerg. Med. 2020. [CrossRef] [PubMed]

82. Cho, J. Investigation on the contaminant distribution with improved ventilation system in hospital isolation rooms: Effect of supply and exhaust air diffuser configurations. Appl. Therm. Eng. 2019, 148, 208-218. [CrossRef] [PubMed]

83. Kalliomäki, P.; Saarinen, P.; Tang, J.W.; Koskela, H. Airflow patterns through single hinged and sliding doors in hospital isolation rooms: Effect of ventilation, flow differential and passage. Build. Environ. 2016, 107, 154-168. [CrossRef]

84. Shao, X.; Hashimoto, K.; Fang, L.; Melikov, A.K.; Naydenov, K.G.; Rasmuseen, C. Experimental study of airborne particle transmission through the doorway of a cleanroom due to the movement of a person. Build. Environ. 2020, 183, 107205. [CrossRef]

85. Mousavi, E.S.; Pollitt, K.J.G.; Sherman, J.; Martinello, R.A. Performance analysis of portable HEPA filters and temporary plastic anterooms on the spread of surrogate coronavirus. Build. Environ. 2020,183, 107186. [CrossRef]

86. Zhou, Y.; Zhang, Z.; Wang, B.; Ren, G.; Qi, H.; Wang, X. Construction time, cost and testing data of a prefabricated isolation medical unit for COVID-19. Data Brief. 2020, 32, 106068. [CrossRef] [PubMed]

87. Hao, L.; Wu, J.; Zhang, J.; Liu, Z.; Yi, Y.; Zhang, Z.; Zhang, E.; Qi, J. Development of a negative pressure hood for isolation and transportation of individual patient with respiratory infectious disease. Biosaf. Health 2019, 1, 144-149. [CrossRef] [PubMed]

88. Knibbs, L.D.; Morawska, L.; Bell, S.C.; Grzybowski, P. Room ventilation and the risk of airborne infection transmission in 3 health care settings within a large teaching hospital. Am. J. Infect. Control 2011, 39, 866-872. [CrossRef]

89. Rosenbaum, R.A.; Benyo, J.S.; O’Connor, R.E.; Passarello, B.A.; Williams, D.R.; Humphrey, B.D.; Ross, R.W.; Berry, J.M.; Krebs, J.G. Use of a portable forced air system to convert existing hospital space into a mass casualty isolation area. Ann. Emerg. Med. 2004, 44, 628-634. [CrossRef]

90. Silich, B.A. Method to Reduce Aerosolized Contaminant Concentration Exposure to Healthcare Workers During the COVID-19 Pandemic when Temporary Isolation Systems Are Required. West. J. Emerg. Med. 2020, 21, 93-98. [CrossRef]

91. Yen, M.Y.; Lin, Y.E.; Su, I.J.; Huang, F.Y.; Huang, F.Y.; Ho, M.S.; Chang, S.C.; Tan, K.H.; Chen, K.T.; Chang, H.; et al. Using an integrated infection control strategy during outbreak control to minimize nosocomial infection of severe acute respiratory syndrome among healthcare workers. J. Hosp. Infect. 2006, 62, 195-199. [CrossRef] 
92. Miller, S.L.; Mukherjee, D.; Wilson, J.; Clements, N.; Steiner, C. Implementing a negative pressure isolation space within a skilled nursing facility to control SARS-CoV-2 transmission. Am. J. Infect. Control 2020, 49, 438-446. [CrossRef]

93. Mendes, A.; Papoila, A.L.; Carreiro-Martins, P.; Bonassi, S.; Caires, I.; Palmeiro, T.; Aguiar, L.; Pereira, C.; Neves, P.; Mendes, D.; et al. The impact of indoor air quality and contaminants on respiratory health of older people living in long-term care residences in Porto. Age Ageing 2016, 45, 136-142. [CrossRef]

94. Aguiar, L.; Mendes, A.; Pereira, C.; Neves, P.; Mendes, D.; Teixeira, J.P. Biological air contamination in elderly care centers: Geria project. J. Toxicol. Environ. Health A 2014, 77, 944-958. [CrossRef] [PubMed]

95. Rodriguez, M.; Valero, A.; Posada-Izquierdo, G.D.; Carrasco, E.; Zurera, G. Evaluation of food handler practices and microbiological status of ready-to-eat foods in long term care facilities in the Andalusia region of Spain. J. Food Protect. 2011, 74, 1504-1512. [CrossRef]

96. Kampf, G.; Todt, D.; Pfaender, S.; Steinmann, E. Persistence of coronaviruses on inanimate surfaces and their inactivation with biocidal agents. J. Hosp. Infect. 2020, 4, 246-251. [CrossRef] [PubMed]

97. Kampf, G.; Jatzwauk, L. Ist die Desinfektion öffentlicher Flächen zur Prävention von SARS-CoV-2 - Infektionen sinnvoll? Gesundheitswesen 2021, 83, 180-185.

98. Anderson, D.J.; Chen, L.F.; Weber, D.J.; Moehring, R.W.; Lewis, S.S.; Triplett, P.F.; Blocker, M.; Becherer, P.; Schwab, J.C.; Knelson, L.P.; et al. Enhanced terminal room disinfection and acquisition and infection caused by multidrug-resistant organisms and Clostridium difficile (the Benefits of Enhanced Terminal Room Disinfection study): A cluster-randomised, multicentre, crossover study. Lancet 2017, 389, 805-814. [CrossRef]

99. Anderson, D.J.; Knelson, L.P.; Moehring, R.K.; Lewis, S.L.; Weber, D.K.; Chen, L.F.; Triplett, P.F.; Blocker, M.; Cooney, R.M.; Schwab, J.C.; et al. For the CDC Prevention Epicenters Program. Implementation Lessons Learned from the Benefits of Enhanced Terminal Room (BETR) Disinfection Study: Process and Perceptions of Enhanced Disinfection with Ultraviolet Disinfection Devices. Infect. Control Hosp. Epidemiol. 2018, 39, 157-163. [CrossRef]

100. Ethington, T.; Newsome, S.; Waugh, J.; Lee, L.D. Cleaning the air with ultraviolet germicidal irradiation lessened contact infections in a long-term acute care hospital. Am. J. Infect. Control 2018, 46, 482-486. [CrossRef]

101. Buchan, A.G.; Yang, L.; Atkinson, K.D. Predicting airborne coronavirus inactivation by far-UVC in populated rooms using a high-fidelity coupled radiation-CFD model. Sci. Rep. 2020, 10, 1-7. [CrossRef]

102. Coutureau, C.; Pascard, M.; Kanagaratnam, L.; Jolly, D.; de Champs, C. Does Copper Prevent Nosocomial Transmission of COVID-19? J. Am. Med Dir. Assoc. 2021, 22, 219-220. [CrossRef]

103. Mantlo, E.K.; Paessler, S.; Seregin, A.; Mitchell, A. Luminore CopperTouch ${ }^{\mathrm{TM}}$ surface coating effectively inactivates SARS-CoV-2, Ebola, and Marburg viruses in vitro. MedRxiv Prepr. Serv. Health Sci. 2020. [CrossRef]

104. Salgado, C.D.; Sepkowitz, K.A.; John, J.F.; Cantey, J.R.; Attaway, H.H.; Freeman, K.D.; Sharpe, P.A.; Michels, H.T.; Schmidt, M.G. Copper surfaces reduce the rate of healthcare-acquired infections in the intensive care unit. Infect. Control Hosp. Epidemiol. 2013, 34, 479-486. [CrossRef] [PubMed]

105. Noyce, J.O.; Michels, H.; Keevil, C.W. Inactivation of Influenza A Virus on Copper versus Stainless Steel Surfaces. Appl. Environ. Microbiol. 2007, 73, 2748-2750. [CrossRef] [PubMed]

106. Warnes, S.L.; Keevil, C.W. Inactivation of Norovirus on Dry Copper Alloy Surfaces. PLoS ONE 2013, 8, e75017. [CrossRef] [PubMed]

107. Warnes, S.L.; Summersgill, E.N.; Keevil, C.W. Inactivation of Murine Norovirus on a Range of Copper Alloy Surfaces Is Accompanied by Loss of Capsid Integrity. Appl. Environ. Microbiol. 2015, 81, 1085-1091. [CrossRef] [PubMed]

108. Sugg, M.M.; Spaulding, T.J.; Lane, S.J.; Runkle, J.D.; Harden, S.R.; Hege, A.; Iyer, L.S. Mapping community-level determinants of COVID-19 transmission in nursing homes: A multi-scale approach. Sci. Total Environ. 2021, 752, 141946. [CrossRef] [PubMed]

109. Waternews Europe. Netherlands: Covid-19 Sewage Measurements Difficult to Interpret. Available online: https://www. waternewseurope.com/netherlands-covid-19-sewage-measurements-difficult-to-interpret/ (accessed on 12 February 2021). 